Historic, Archive Document

Do not assume content reflects current scientific knowledge, policies, or practices. 



\section{Fruit, Shade and OrnamentalTrees}

GROWN FOR THE NORTHWEST

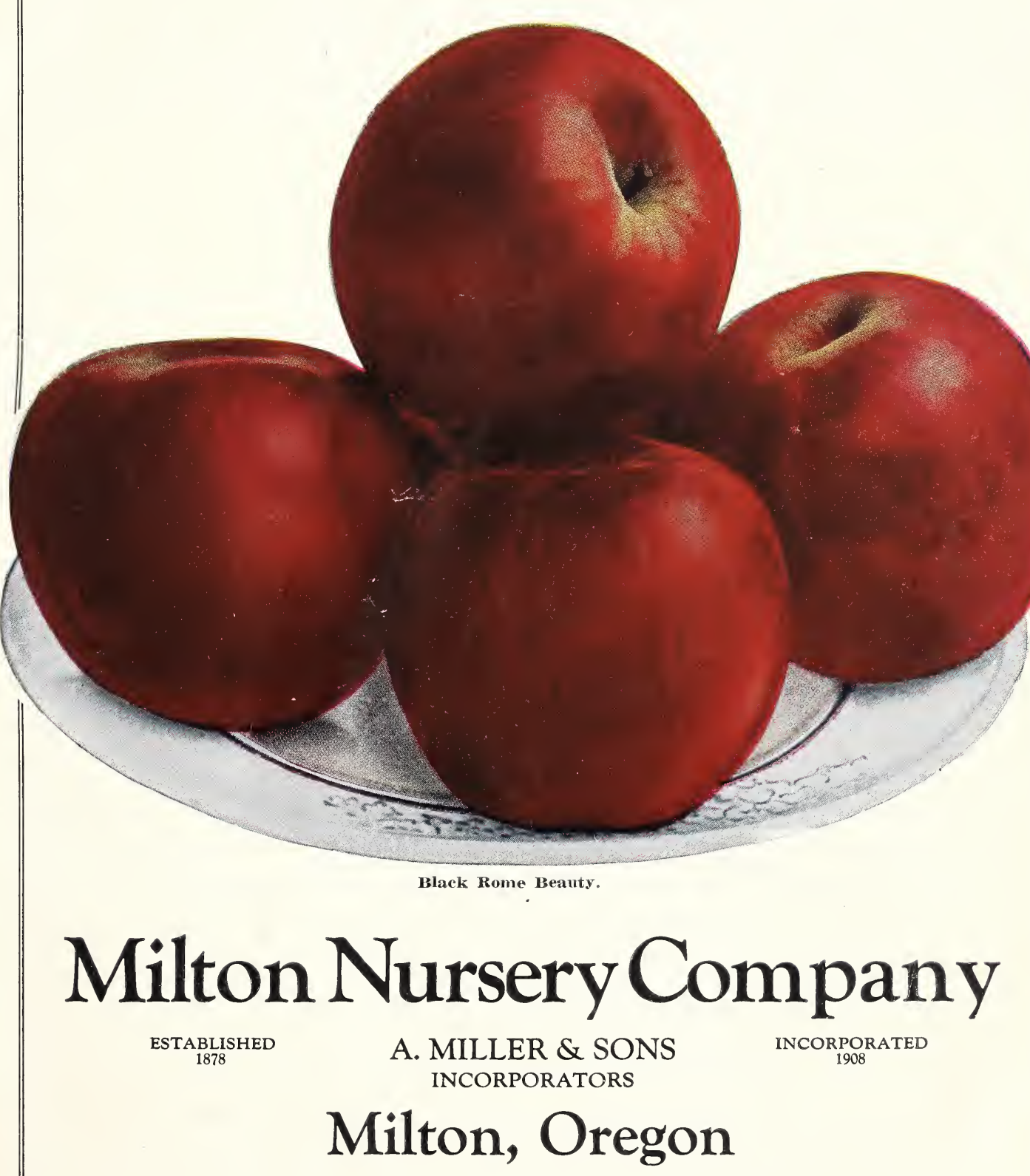




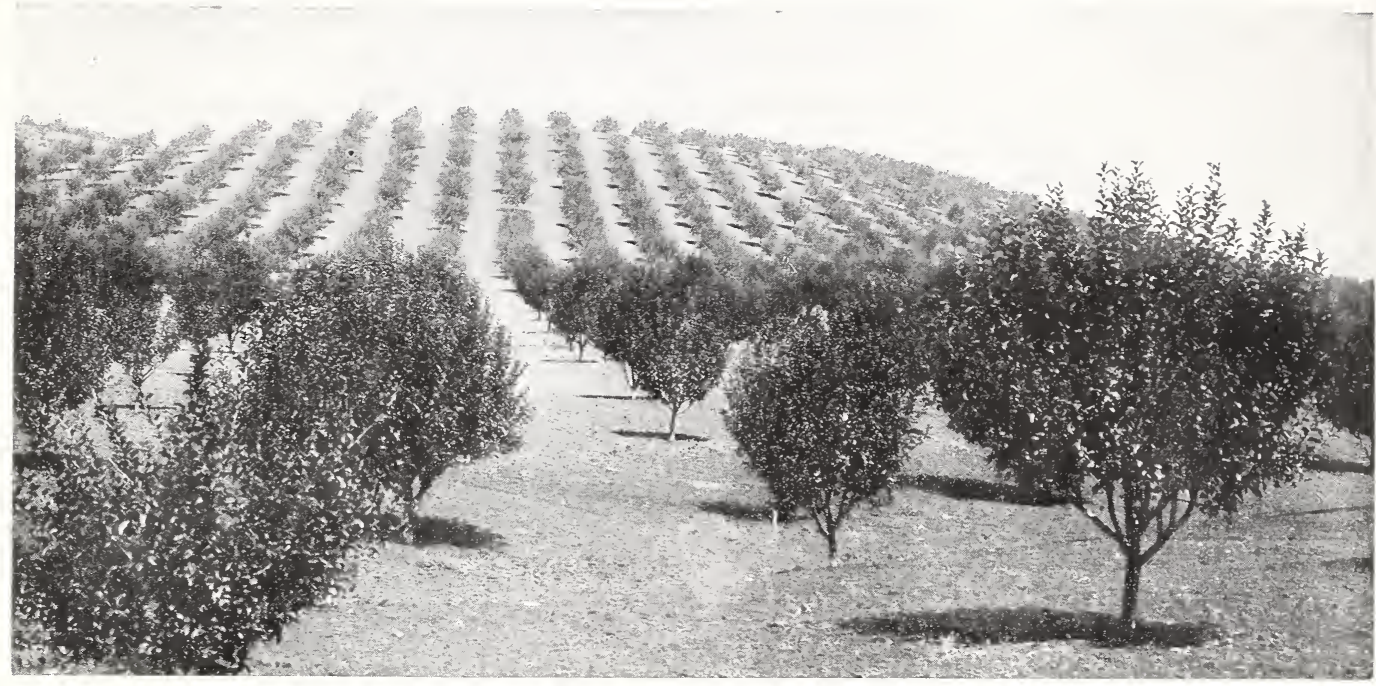

\section{Please Read}

1.-We begin shipping in the Fall, about the 20th of October, continuing until freezing weather, and usually in the Spring from March 1 st to the middle of April.

2.-Orders should be sent in as early as pos sible, that there may be plenty of time for shipping long distances when necessary.

3.-Buyers ordering by letter should write out their order plainly. This will prevent mistakes in the hurry of the packing season. Also, write your nams, postoffice, state and county as plain as possible.

4.-Give plain and specific directions. When none are given we forward according to our best judgment, but in no case do we assume any responsibility after the delivery of the stock in good condition to the forwarder.

5.--Those who are not acquainted with the merits of the different varieties will do well to leave the selection to us, stating if wanted for family or market use, and giving the proportion of Summer, Fall, and Winter, as we sha!l send only such as give general satisfaction, and our long experience enables us to select varieties adapted to the locality. The description of the various kinds of fruits, etc., in this catalog is, in the main, correct, but sometimes altitude, soil, and climatic conditions and cultivation influence the quality, color, size and season to a noticeable degree, so much so that customers may doubt the genuineness of certain varieties of fruit. Before condemning anything as untrue to name, always allow the foregoing to have proper weight.

6.-We take great care to have our trees true to name, cutting all our scions and buds from bearing trees ourselves, and not trusting it to our hired men, but if any should prove untrue we will replace the same or refund the money. It is, however, understood between the purchaser and ourselves, that in no case will we be held liable for a greater sum than the original price paid for the trees that prove untrue.

7.-All the trees and plants are carefully labeled and securely packed in the best possible manner, at catalog prices, and delivered to carriers, for which no extra charge is made for cartage. Prices are f. o. b. Milton, Oregon.

8.-Remittances may be made by bank draft, express checks, postal orders or registered letters.

9.-Our customers are requested to notify us immediately if any errors occur in filling their orders, so that we may at once correct them, as we desire to conduct our business in all respects satisfactory to those who favor us with their confidence.

10.-TERMS. Orders with cash in full transportation charoes paid by Milton Nursery Company. Otherwise transportation charges paid by customer. C. O. D. orders must be accompanied by one-tourth in cash. Transportation charges paid by customer.

SPECIAL NOTICE.-Those only who can show a contract issued during the current year, with our seal and signature attached, are authorized to solicit orders for us.

Address all communications to the Company. Inquiries relative to stock and prices will be promptly answered, and any information or advice that we are able to impart will be gladly given. No business transacted o. Saturday. Address,

MILTON NURSERY COMPANY, Milton, Oregon. 


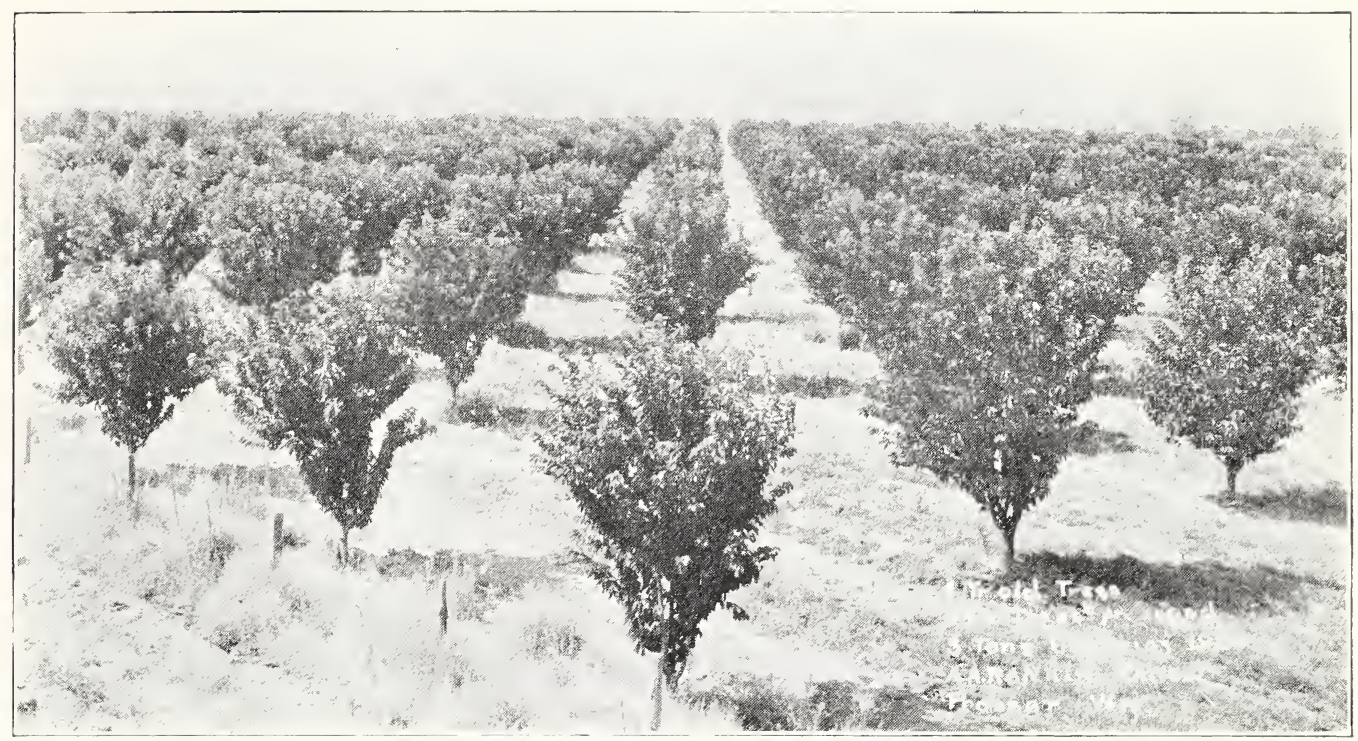

Four-year-old Bing Cherry Orchard Planted at Prosser, Washington, with Milton Nursery Company Trees, 1922.

\section{INTRODUCTION}

We take great pleasure in presenting herewith our forty-fourth annual catalog with rerised and complete descriptions. The simple and systematic arrangement which has been adopted, combined with a complete index, renders the publication very convenient for reference.

NEARIY FIFTY YEARS AGO A. Miller, now deceased, started the Milton Nursery, in what is known as "The Garden Spot" of the Walla Walla Valley, just in the edge of the beautiful town of Milton, Umatilla County, Oregon, and one-fourth mile east of the depot. on the main line of the $O$. W. \& N. Railroad between Spokane and Pendleton; also one. fourth mile east of the depot on the Walla Walla Valley Traction Company road. From a small beginning, it grew steadily, under his careful, experienced management, it being his constant aim to produce stock absolutely true to name and peculiarly adapted to the climate and other conditions of the Northwest. That he was successful in his efforts we believe to be fully proven by the large number of thrifty orchards grown from stock from our nurseries, now bearing fruit in abundance throughout the western states.

In $1896 \mathrm{~S}$. A. Miller secured an interest in the nursery and assumed the management of the business. At that time more ground was secured and a larger acreage planted to nursery stock, and the business continued to grow. A few years later the names of $G$. $W$. and C. B. Miller were added to the firm, and in the Spring of 1908 the business had reached such a ereat volume that in order to better facilitate its management, the firm was incorporated, with a capital stock of $\$ 50,000.00$ under the name of Milton Nursery Company, the stock being fully paid up and all retained by the old firm of $A$. Miller \& Sons.

The company now has THREE HUNDRED AND TWENTY-EIVE ACRES deroted exclusively to the growing of nearly TWO MILLIONS of fruit, shade, ornamental trees and shrubbery. The soil on which we grow our trees is per- fectly adapted to the raising of nursery stock and producing a fine system of golden yellow fibrous roots, as well as unusually healthy and thrifty tops.

We thank our friends and customers for the liberal patronase we have received for more than a quarter of a century, and believing this is only attained by honest and fair dealing with all, we hope, in the same manner, to retain the trade and confidence already placed in our nursery, as well as to increase it.

Knowing that never before have we offered a finer stock to the public, we feel that we need no other guarantee than our record of the past years. It is our constant aim and intention to supply only the best stock at lowest prices consistent with the quality of the goods offered, and all intending purchasers will find it to their advantage to give us an opportunity to furnish estimates upon their lists. We, therefore, solicit your orders, promising that every endeavor will be made to make each customer satisfied.

MILTON NURSERY COMPANY, Milton, Oregon.

\section{We Do Not Quote Prices in This Catalog}

The nucertainty of conditions in the nursery field, owing to such items as labor, packing material and other items that govem prices on nursery stock; also because of the fact that the supply on many varieties is so limited, makes our old time custom of putting permanent price on every item in catalog as heretofore, impractical and impossible.

So we have done the next best thing and enclosed a price list with this book which you can use in making up your order. 


\section{Fruit Department}

\section{To Washington, Oregon, Idaho and California Purchasers}

Purchasers from these points will remember that we are under bonds to the amount of $\$ 1,000.00$ to $\$ 5,000.00$ for license to ship trees in said places, which is required by law. If any of our nursery stock is found to be infected with pests of any kind, we are held responsible by these states and the infected stock is burned. While we never, to our knowledge, have sent out an infected tree, this will serve for an extra warrant that stock from our nursery will be clear from all insect pests. And furthermore, we are in the nursery business to stay, and we realize that our future success depends on sending out only clean, thrifty trees, true to name.

\section{Hints on Planting, Culture Pruning, Etc.}

All communications relative to nursery stock and prices will be attended to promptly, and any information or advice that we are able to impart, when desired, will be given freely.

What to Plant. Select thrifty young trees in preference to old or very large ones; the roots are more tender and fibrous and bear transplanting better and are far more apt to live. They can also be more easily trimmed and shaped to any desired form, and in the course of a few years will usually outstrip the old ones in growth. The largest and most successful planters almost invariably select one-year-old trees.

Treatment. When the trees are received frcm the nursery, bury the roots in well pulverized soil until you are ready to plant them. Never expose the roots to sun or wind. If trees are received in a frozen state, place the package unopened in a cella.r, away from frost and heat, until thawed out, then unpack. If partly dried from long exposure, bury entirely in the ground, or place in water from twelve to twenty-four hours.

Planting. Nake the holes large enough to admit the roots without cramping or bending and deep enough to bring the tree to its natural depth. The fine surface soil should be used in covering the roots, and this should be carefully worked among them. If the ground is dry it is well to pour in some water when the hole is partially filled. See that the ground is firmly and solidly packed over all parts of the roots, so there will be no opportunity for dry air or frost to enter and destroy roots deprived of the full benefit of their natural protection. Omission to pack the earth solidly is a more frequent cause of failure in planting nursery stock than any other. Fill the holes full enough to be even with the surrounding surface after the fresh earth settles. Large standard trees should be staked and tied so that the wind will not loosen the roots. Be sure to cut the tops back fully one-third soon after planting; more is better. 
TRIANGULAR METHOD
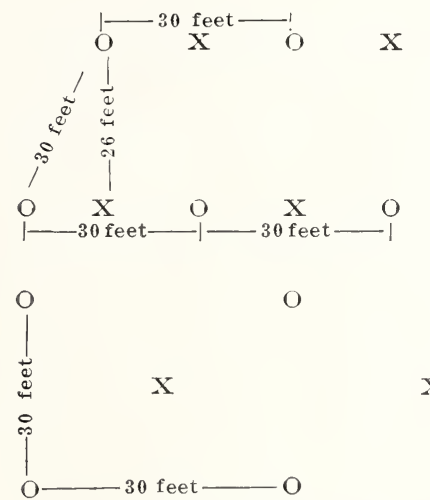

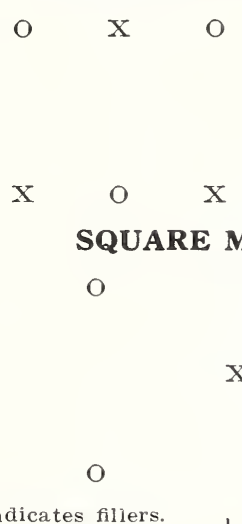

$\mathrm{O}$ indicates permanent trees. $\mathrm{X}$ indicates fillers.

Rule, Equilateral Triangle Method. Divide the number required to the acre, "square method," by the decimal .866 . The result will be the number of plants required to the acre by this method.

\begin{tabular}{|c|c|c|c|c|c|c|c|c|c|c|c|c|c|c|c|c|c|c|}
\hline & & & istanc & & & & $\begin{array}{l}\text { Square } \\
\text { Method }\end{array}$ & $\begin{array}{r}\text { Triangular } \\
\text { Method }\end{array}$ & & & & istanc & & & & & $\begin{array}{l}\text { uare } \\
\text { thod }\end{array}$ & $\begin{array}{r}\text { Triangular } \\
\text { Method }\end{array}$ \\
\hline 1 & foot & apart & each & way, & No. & Plants & . . . 43,560 & 50,300 & 12 & feet & apart & each & way. & No. & Plants. & $\ldots$ & 302 & 348 \\
\hline 2 & feet & "“ & “ & "“ & " & “ & $\ldots 10,890$ & 12,575 & 14 & " & ". & “. & “. & 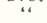 & " & $\ldots$ & 222 & 256 \\
\hline 3 & " & “ & “" & “" & “" & “" & . . 4,840 & 5,899 & 15 & “" & “ & “ & “ & “" & “ & $\ldots$ & 193 & 222 \\
\hline 4 & “. & “ & “" & “. & “ & " & $\ldots 2,722$ & 3,143 & 16 & “. & “ & “ & “ & “" & “ & $\ldots$ & 170 & 181 \\
\hline 5 & “ & “ & “" & “. & “" & 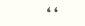 & $\therefore 1,742$ & 2,011 & 18 & “ & “ & “ & " & “ & “ & $\ldots$ & 134 & 154 \\
\hline 6 & .“ & " & “. & “" & “. & “ & . 1,210 & 1,397 & 20 & “" & " & “ & . & “ & “ & $\ldots$ & 109 & 125 \\
\hline 7 & " & “. & "“ & “. & “ & “ & $\ldots 888$ & 1,035 & 25 & “" & “. & “" & “" & “" & “ & $\ldots$ & 69 & 79 \\
\hline 8 & “، & “ & “" & “" & “" & “ & $\ldots$ & 785 & 30 & “" & " & ". & " & “" & “ & $\ldots$ & 48 & 56 \\
\hline 9 & “ & “. & “. & ". & “" & “ & 537 & 620 & 35 & “ & '。 & “ & “. & “" & “" & $\ldots$ & 35 & 40 \\
\hline 10 & “ & “" & “ & “ & “. & " & $\ldots$ & 502 & 40 & “ & ". & “ & " & ، & " & $\ldots$ & 27 & 31 \\
\hline
\end{tabular}

\section{Apples}

The Apple will grow on a variety of soils, but seldom thrives on very dry sands, or soils saturated with moisture. A deep, strong, gravelly, marly or clay loam, or a strong sandy loam with gravelly sub-soil, produces the best crops, and the highest flavored fruit, as well as trees of the greatest longevity. Always dig the holes large enough to receive the roots without crowding; if one-year trees are planted, cut back to required height to form the head; if two-year-old are planted cut back all laterals about two-thirds.

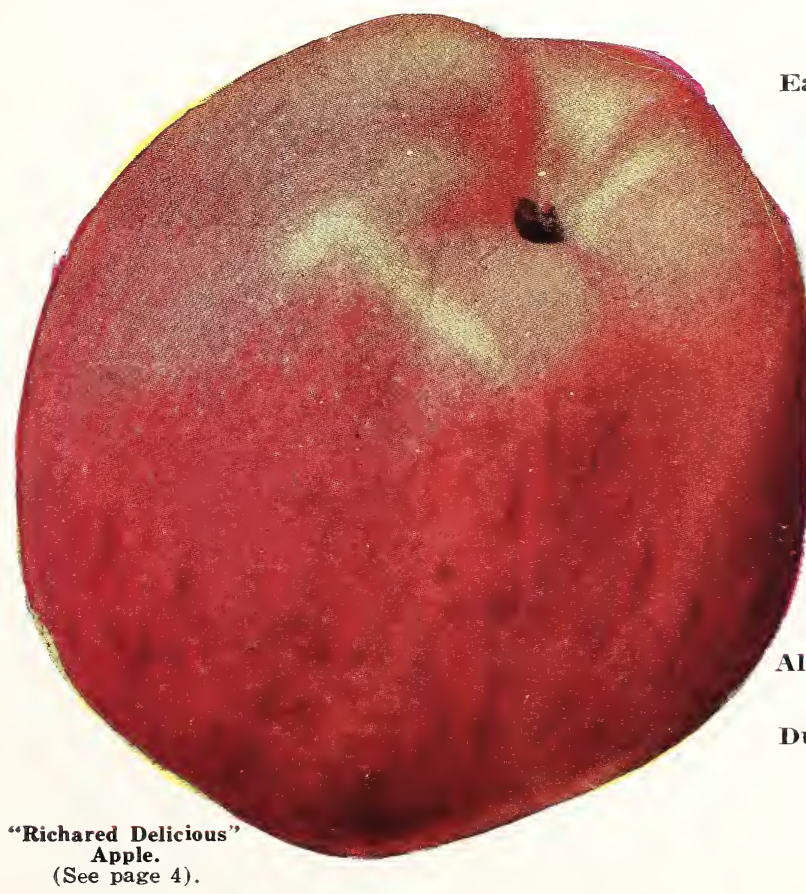

\section{Summer Apples}

Early Goodwin. Perfectly hardy, bears an immense crop of fruit annually. Fruit large size, smooth, beautifully colored. Flesh white, tender, juicy, sub-acid; excellent for cooking and dessert.

Early Harvest. Fruit medium size, skin yellow, flesh very white, tender, and juicy; ripens middle of July.

Red Astrachan. Rich, juicy, and acid; strong growing tree, perfectly hardy, and a good bearer; July.

Red June. Medium size Apple of good quality; productive, hardy; July and August.

Sweet Jume. Rather large, paleiyellow, sweet and juicy; last of August.

Yellow Transparent. Earliest Apple grown. Flesh fine-grained, juicy, rich sub-acid; the tree is perfectly hardy.

\section{Fall Apples}

Autumn Strawberry. Color, streaks of light and dark red; tender, juicy, sub-acid, fine. September to October.

Alexander. Of Russian origin; large, deep red; flesh yellowish white; crisp, tender, with pleasant flavor. Very good. October.

Duchess of Oldenburg. Flesh juicy, sprightly, sub-acid; very hardy; very early and abundant bearer. 


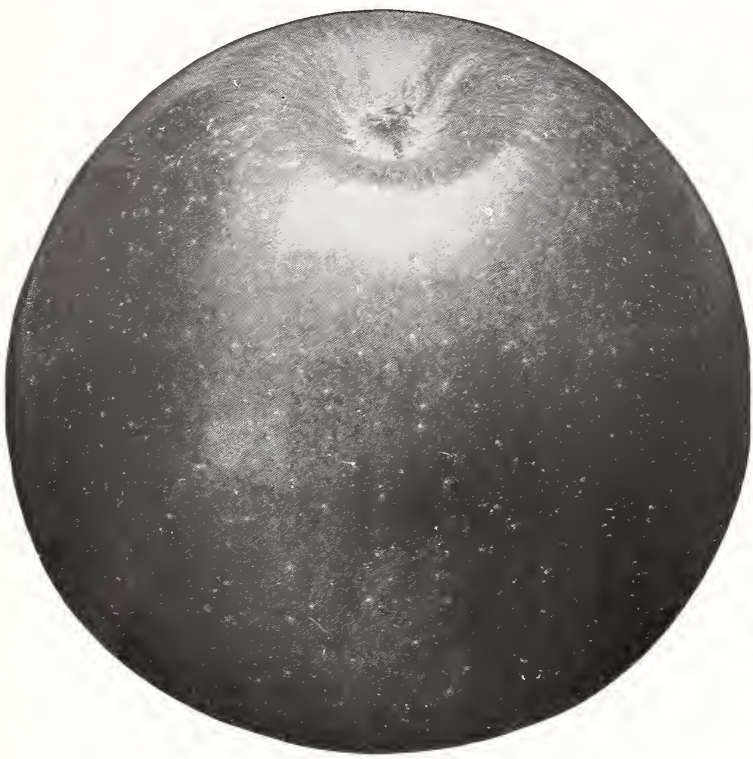

IcIntosh Red Apple.

Gravenstein. Large, striped and beautiful; tender, juicy and high flavored; vigorous and productive. September to October.

Jefferies. Flesh white, tender, juicy, with a rich, mild, sub-acid flavor. The best eating Apple grown in its season; September and October.

Maiden's Blush. Fine grained, tender, pleasant acid flavor; trees extremely hardy; very good. September to October.

Rambo. A very popular Autumn fruit. It is valuable for the table or kitchen; fruit of medium size with a rich flavor. October to December.

Twenty Ounce. Very large; yellow, striped with red; quality good. Oct. to Déc.

\section{Winter Apples}

Arkansas Black. Fruit large, smooth and round, very black, dotted with whitssi specks. Flesh yellow, very juicy and a delicious flavor.

Bismarck. Tree somewhat dwarf in habit of growth: thick, heary foliage. Fruit large. handsome. 'Tree a prolific and early bearer. Hardy.

Baldwin. Flesh yellowish white with an agreeable mild acid and yet high flavor. Norember to March.

Ben Davis. Showy, rather coarse quality; productive. A long keeper.

Black Ben Davis. Of the Ben Davis family. Not distinguished from Gano.

BLICI HOMI BHSUTY. Identical with Rome Beauty and Red Rone Beauty in vigor. early bearing. hardiness and production. Color. very dark, solid red. almost as dark as Irkansas Black. Quality superior to ordinary Rome Beanty, fine grain, melting. Best of all Rome Beauty types: will no doubt take the place of any other strains. Packs out highest percentage of extra fancy apples. Sold under contract only. We control the original trees and are the only growers and distributors of this new variety. This and Richared Delicious are the coming conmercial varieties.

Bailey's Sweet. Flesh white, tender, almost melting, with a honeyed sweet flavor. The best late sweet Apple. October to November.

Fameuse or Snow. Flesh snowy white; juicy and pleasant; tree very hardy. Norember to December.
Blue Peammin. Tree hardy. Fruit large, dark red, rich, sub-acid. December to February.

Delicious. Is all that is claimed for it. Is a thrifty grower; very hardy; has never failed to bear full crop. Color about half way between Rome Beauty and Jonathan: solid; will keep until February. Quality and flaror unsurpassed.

Grimes Golden Pippin. Flesh erisp, tender, juicy, rich, sub-acid; rery good. December to March.

Gano or Black Ben Davis. Fine grained, tender, pleasant, mild, sub-acid; tree healthy, vigorous and hardy; an annual and prolific bearer. February to May.

Golden Russet. Medium size, rellow covered with dull russet. Flesh whitish yellow, fine srained, mild sub-acid. Good.

Jonatlın. Fine grained, very tender and finely flavored; tree very productive. An excellent market rariety. December to February.

King (King of Tompkins County). Flavor like the Baldwin. One of our best Winter Apples. Very salable. November to December.

McIntosh Red. Taluable, hardy, Canada sort; medium size, nearly covered with dark red; flesh white, fine, very tender, juicy and refreshing. A good, annual bearer. November to February. A profitable Apple in high altitudes. A leader in Montana.

Northern Spy. Flesh white, fine grained, ten der, slightly sub-acid and delicious flavor; tree a good grower; a long keeper.

Red Ronie Beauty. A select strain of the ordinary Rome Beauty, identical in vigor and production. Color of fruit darker and solid red. Produces twenty-five to fifty per cent more fancy Apples than the old strain of Rome Beauty. Not as dark as Black Rome Beauty

Rhode Island Greening. Skin smooth, dark green, becoming yellow when thoroughly ripe; rich, tender and fine grained. Norember to December.

Richared Delicious. An improved Delicious in color, which is solid, dark red. A sport from the Delicious, originating in one of the famous Apple sections of the Northmest. Firmly established by several years of selection and fruiting. Quality considered better than parent. Long keeping, stores well; one of the most valuable additions to the list of commercial apples. We have purchased the right io propagate. Sold only on contract. This and the Black Rome Beauty we beliere are the coning commercial rarieties.

Spokane Beauty. Largest Apple known; color a greenish yellow, shaded and striped with deep red; flesh crisp, juicy and rich, with a delicious high flavor; unsurpassed for cooking and drying; a long keeper.

Spitzenbura. Esopus. Truly delicious Apple; fruit striped and splashed with red; flesh yellow, rather firm, with a delicious rich acid flavor. November to April.

Stayman Winesap. Tree much in appearance like Winesap. Fruit medium to large; greenish yellow, striped with dark, dull red; tender, juicy, rich, mild sub-acid. Jan to May.

Tolnan Sweet. Medium; pale vellow, slightly tinged with red; firm, rich and very sweet; productive. November to April.

Winesap. Medium, dark red, sub-acid; excellent; an old favorite market Apple. December to May.

White Winter Pearmain. Above medium size; roundish, oblong, conic; pale yellow, with a slight blush; extra high flavor; one of the best. December to March.

Wealtiry. Tree hardy, vigorous, productive; a beautiful and excellent fruit; skin smooth, white yellow, shaded with deep rich red; December to February. 
Wagener. Medium to large; deep red in the sun; flesh firm, sub-acid and excellent; very productive and bears very young. December to April.

Winter Banana. Fruit large, fine grained, a beautiful golden yellow, shaded with bright red, unusually handsome. Flesh of golden yellow, very large and highly perfumed and considered the finest flavored Apple grown. Tree hardy. An early and prolific bearer. November to May.

Wolf River. Fruit very large and handsome, being covered with two shades of light and dark red; flesh whitish, juicy, breaking, pleasant sub-acid. A good bearer. November.

Yellow Newtown Pippin. This stands as high as any Apple in our markets, and is one of the best keepers; flesh firm, crisp, juicy and with a fine flavor. January to June.

Yellow Bellfower. Large, oblong; skin yellow, with a beautiful tinge of red on the sunny side; flesh crisp, juicy with a delicious high flavor. October to January.

\section{Crab Apples}

Hyslop. Produced in clusters; dark, rich red; flesh yellowish, sub-acid; good for culinary uses and cider. Good last of September.

Red Siberian. A beautiful little fruit, produced in rich clusters; highly esteemed for preserving. First of September.

Transcendent. A handsome little Apple for dessert and preserving. Early Autumn.

Whitney's No. 20. One of the largest Crabs; glossy green, splashed carmine, juicy, pleasant; great bearer; excellent for cider. August.

\section{Pears}

The best soil for this fruit is a strong loam of moderate depth on a dry sub-soil. Trees should be handled in same manner when planting, as any other fruit tree, not failing to cut back tops, which insures better growth. Most varieties are much finer in flavor if picked from tree before being fully mature, and allowed to ripen off the tree.

\section{Summer Varieties}

Bartlett. Large, buttery, juicy, high flavored great bearer. One of the most popular of all the Summer varieties. August to September.

Clapp's Favorite. Fruit large; skin thin, pale yellow; flesh white, fine grained, juicy, buttery, melting, rich, sweet, vinous; a little perfumed; very good. Ripens two weeks earlier than Bartlett.

\section{Autumn Varieties}

Beurre d'Injou. A fine Pear; rather large; flesh yellowish white, buttery; fine grained, rich, vinous flavor. Tree a good grower and fine bearer. October and November.

Beurre bosc. Large, deep vellow russet colored, long neck. Half melting, juicy, delicious with pleasant odor. Tree good grower and productive. Good shipper. September.

Doyenne du Comice. Tree moderately vigorous, upright grower. Fruit large, roundish. Skin greenish yellow, becoming fine yellow at maturity, often lightly shaded with crimson and fawn in the sun. Flesh white, fine melting, a little buttery, juicy, sweet, rich, slightly aromatic. Very good. October to November.

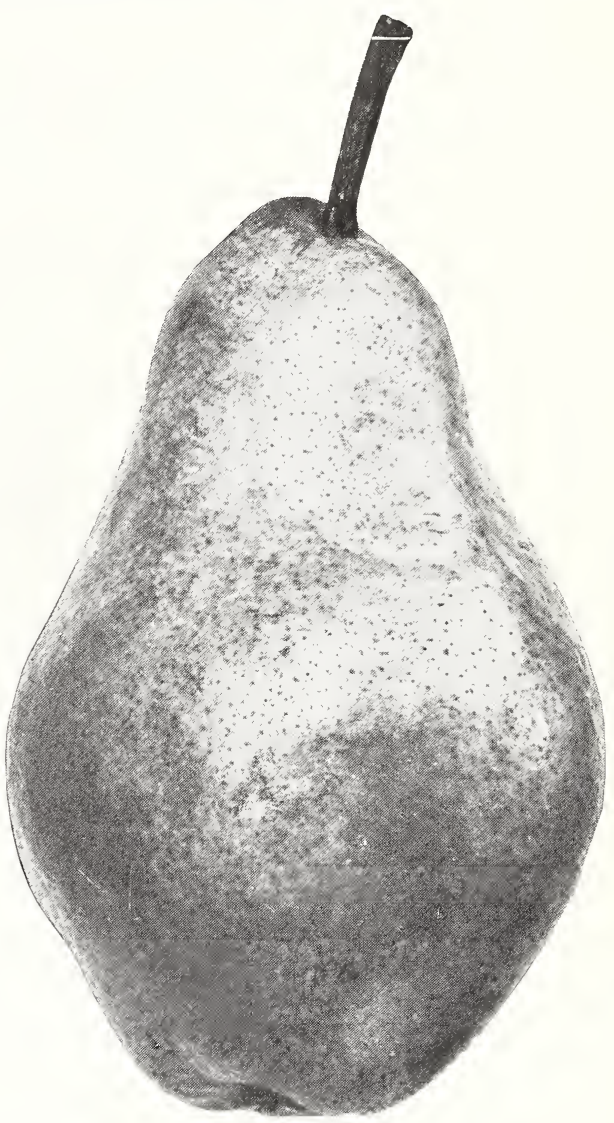

Bartlett Pear.

Flemish Beauty. Fruit large, pale yellow, becoming reddish brown at maturity on the sunny side. Flesh yellowish white, juicy, melting, very saccharine and rich. Last of September.

Louise Bonne de Jersey. Rather large, greenish yellow, with a bright red cheek; juicy, buttery and melting; excellent, very productive; a fine grower. September and October.

seckel. Small, yellowish brown, red cheek; sweet, juicy, melting. Best. September and October.

White Doyenne (Fall Butter). Medium; pale yellow, with a faint blush; fine flavor. October to November.

\section{Winter Varieties}

Winter Nelis. Tree hardy and thrifty; a very delicious Winter Pear of medium size; flesh yellowish white, fine grained, buttery and very melting, abounding with juice of a rich aromatic flavor; good to very good. December to February.

Winter Bartlett Fruit large, closely resembling the Bartlett in shape and appearance perfectly smooth; flesh tender, juicy and melting; flavor similar to the Winter Nelis, but season a little later, and as good as can be desired. 


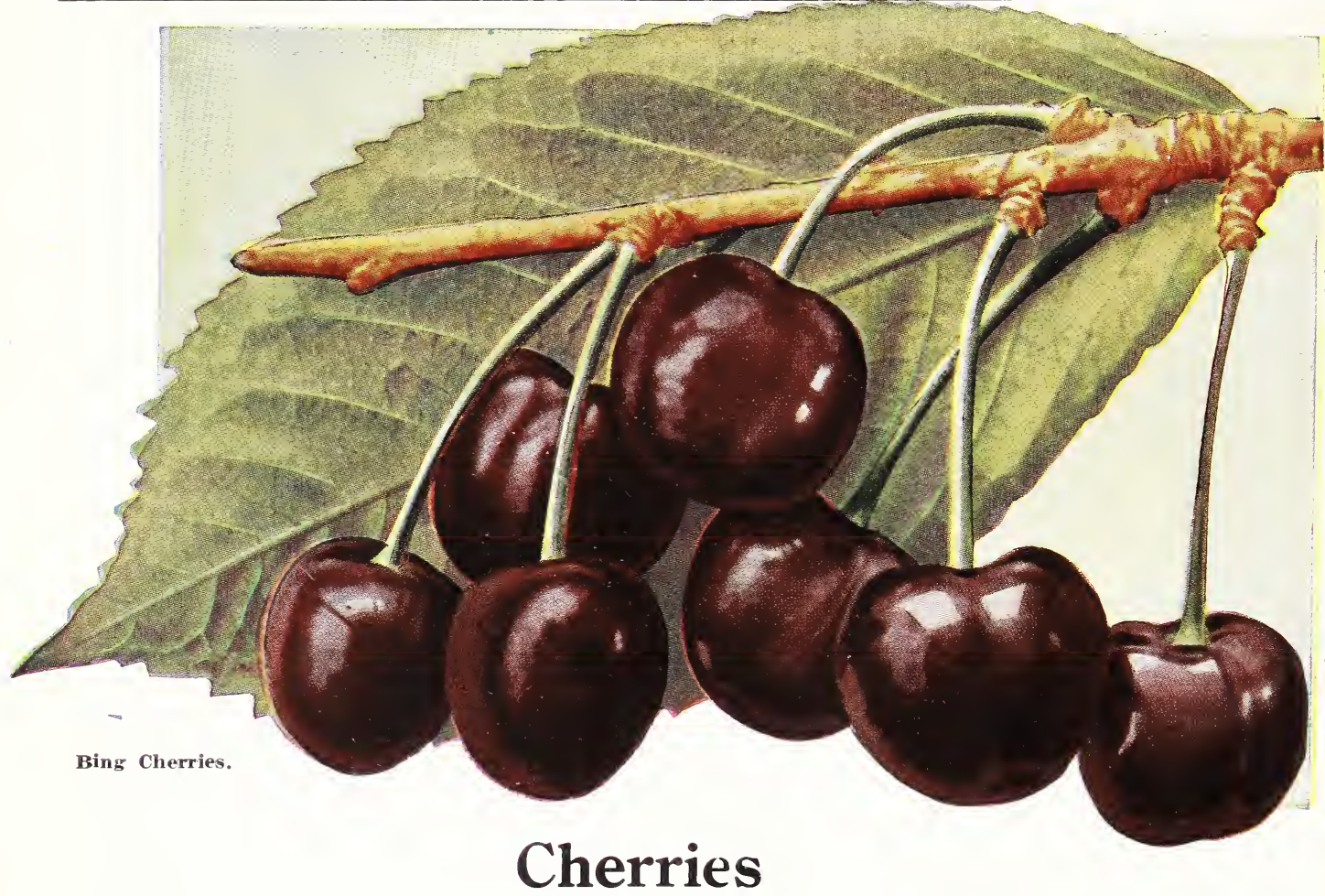

In planting a Cherry orchard care should be taken not to plant the trees too close together; select a dry soil for the Cherry, as a rule, although it is so hardy a tree that it will thrive in a great variety of soils, yet a good sandy, or gravelly loam is best. Use same care in planting as other trees.

Orchardists are resorting more and more to the planting of varieties of Cherries that are strong pollenizers. Experience seems to demonstrate that such varieties as Black Tartarian, Black Republican, and Centennial are the best varieties to use for this purpose. Usually about one in every ten trees has proven to be the right proportion to use of these pollenizers.

\section{Sweet Varieties}

Bing. This grand new black Cherry was originated by Seth Luelling, of Milwaukie, Ore. Almost as large again as the Black Republican: flesh very solid, flavor of the highest quality; tree thrifty, upright grower, very hardy and productive; a fine shipping and market variety. First of July.

Black Republican. Fruit large, very dark color when ripe; very rich and solid and an excellent keeper. Middle of July. Pollenizer.

Black Tartarian. Very large, purplish black, half tender; flavor mild and pleasant. Tree remarkably vigorous, erect and beautiful grower, and an immense bearer. Ripe last of June and beginning of July. Extensively used as pollenizer.

Centennial. Very much like the Royal Ann in shape and color. As large, sweet and good. Ripens a few days later. Extensively used as pollenizer.

Early Purple. An early variety, ripening the last of May in favorable season; skin dark red, almost black; flesh juicy and rich.

Lambert. Size very large; form roundish, heart-shaped; cavity medium, regular, with gradual slope; stem long, slender, suture of medium depth, wide, extending from cavity to apex, which is of a round russet dot in a broad depression; surface smooth, glossy; color dark purplish red, with numerous minute, indented russet dots; flesh dark purplish red with whitish veins, meaty and of fine texture; semi-cling, small seed for so large a fruit; flavor sweet or very mild sub-acid, aromatic, rich. Quality very good and an excellent shipper.

Royal Ann. Fruit large; very dark color when ripe, very rich and solid and an excellent keeper. Middle of July.

\section{Dukes and Morellos}

Early Richmond (Kentish). Medium size, bright red; flesh melting, juicy and rich acid flavor. Last of June.

English Morello. Medium to large; blackish red, rich, acid, juicy and good.

Late Duke. Fruit large, roundish, rich, dark red, sub-acid. Tree hardy; very valuable. Ripens last of July.

May Duke. This is one of the best hardy Cherries; medium size, dark red, melting, rich and juicy. First of June.

Montmorency. Large. Tree very hardy and immense bearer, fruiting when young and is a regular bearer of fine crops; fruit large, fine flavor, shining red, valuable everywhere, especially west of the mountains in coast sections where it is planted for commercial canning purposes. One of the finest acid Cherries. About a week later than Early Richmond.

Olivet. Tree hardy; fruit very large; a shining deep red sort; tender, rich and good. Last of June. 


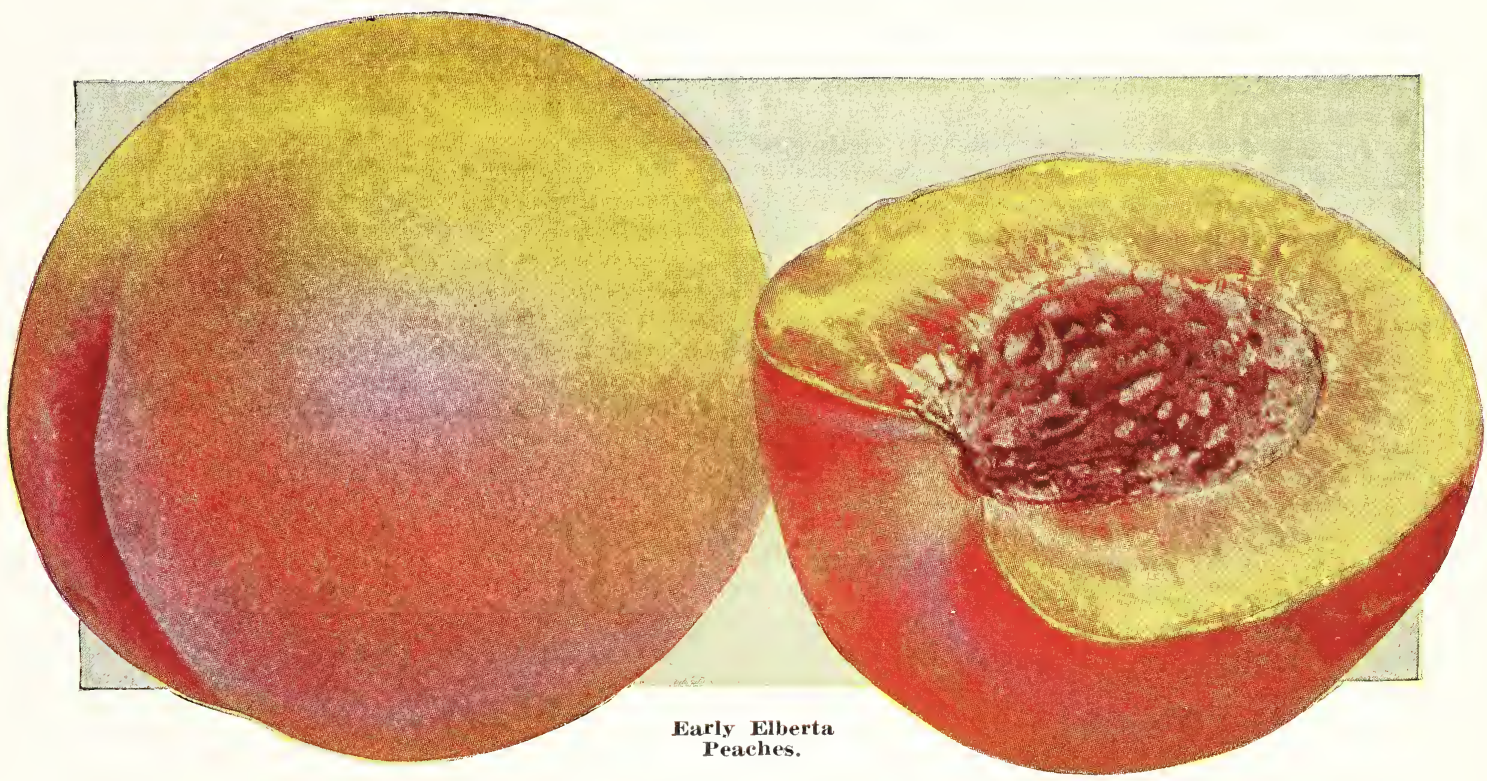

\section{Peaches}

The best soil for the Peach is a deep, rich, sandy loam. Trees should be vigorously pruned back when planted to form good, strong heads.

Arp Beauty. Of the Elberta type, but hardier in tree, bud and bloom; very prolific. Skin yellow, blushed and mottled bright crimson; flesh yellow, firm, juicy, excellent flavor. Ripens when Alexander is going out. An extra good shipper. Sometimes freestone when ripe. The best early Peach grown.

Alexander. Medium to large; greenish white. covered with a deep rich red; very juicy, clinging to stone. Best early market variety.

Champion. It is a large, handsome Peach, with a creamy white skin and beautiful red cheel. In flavor it is exquisite, and is a true freestone. Ripens about the middle of July.

Early Crawford. A magnificent, large yellow Peach of good quality. Its size, beauty and productiveness make it one of the most popular varieties. Extensively planted. Freestone.

Elberta. Very large; skin golden yellow where exposed to sun, faintly striped with red. Flesh yellow, very fine grain, juicy, rich and sweet. Tree very prolific and presents a handsome appearance. Freestone. Sept.

Early Flberta. Freestone, midseason, of the Elberta type. Large golden yellow flesh, far better in quality than the Elberta, sweeter and finer grained. Tree strong grower, has tendency to thin itself like Elberta, carrying moderate loads of fruit. A splendid canning variety, remaining solid and good color. It passes on the market as the Elberta but the customer gets a better Peach and the grower repeat orders. Pipens about ten days before Elberta, along with Early Crawford.

Hale's Early. Medium, nearly round; skin mottled red, dark red cheek. Flesh white, juicy, melting, high flavored; freestone. Aug.

Heath Cling. A most delicious cling. Very large; skin downy, creamy white with faint blush of red; flesh white, slightly red at the pit; very tender, juicy and sweet; valuable for canning; season early September
Indian Peach. Very large, dark purple clingstone. Flesh dark purple, firm and rich. September.

J. H. Hale. In size and color surpassing Elberta; freestone; solid, free from stringiness, excellent flavor; a good keeper and shipper. Coming commercial Peach.

Lemon Cling: Large size, lemon color. One of the best market varieties, on account of its firmness, size and excellent qualities. Sept.

Late Crawford. A superb, large, yellow, freestone Peach; very rich. Last of September.

Mayflower. Earliest of all varieties, well colored all over, tree vigorous, bears young and heavy; good flavor and size.

Malta or Muir. Very sweet and firm, yellow, with sometimes faint blush. Large, very free, pit quite small. Most popular drying and canning variety on the coast. August.

Orange Cling (Runyan's). Fruit large, yellow: rich, sugary, vinous flavor. Tree heavy bearer; hardy.

Perfection. The fruit is of the largest size, yellow, with a beautiful blush cheek. The flesh is thick and very fine grained, yellow, with red around the pit, which is nearly as small as a prune seed. Its tough skin, firm flesh and good keeping qualities place it in the lead for a desirable shipping and market variety. Ripens from 10 th to 15 th of September. We cannot recommend this new Peach too highly to our friends and patrons.

Salway. $\Lambda$ large, vellow English peach, with deep yellow flesh; very juicy, melting and rich. A valuable late market variety.

Slappey. Fruit yellow, good keeper; excellent flavor, fine grained, rich. Hardy, best medium early vellow Peach.

Triumph. Earliest yellow flesh Peach; ripens a few days later than Alexander, blooms late; sure and abundant bearer; strong, vigorous grower; fruit good size; yellow, with red and crimson cheek. 


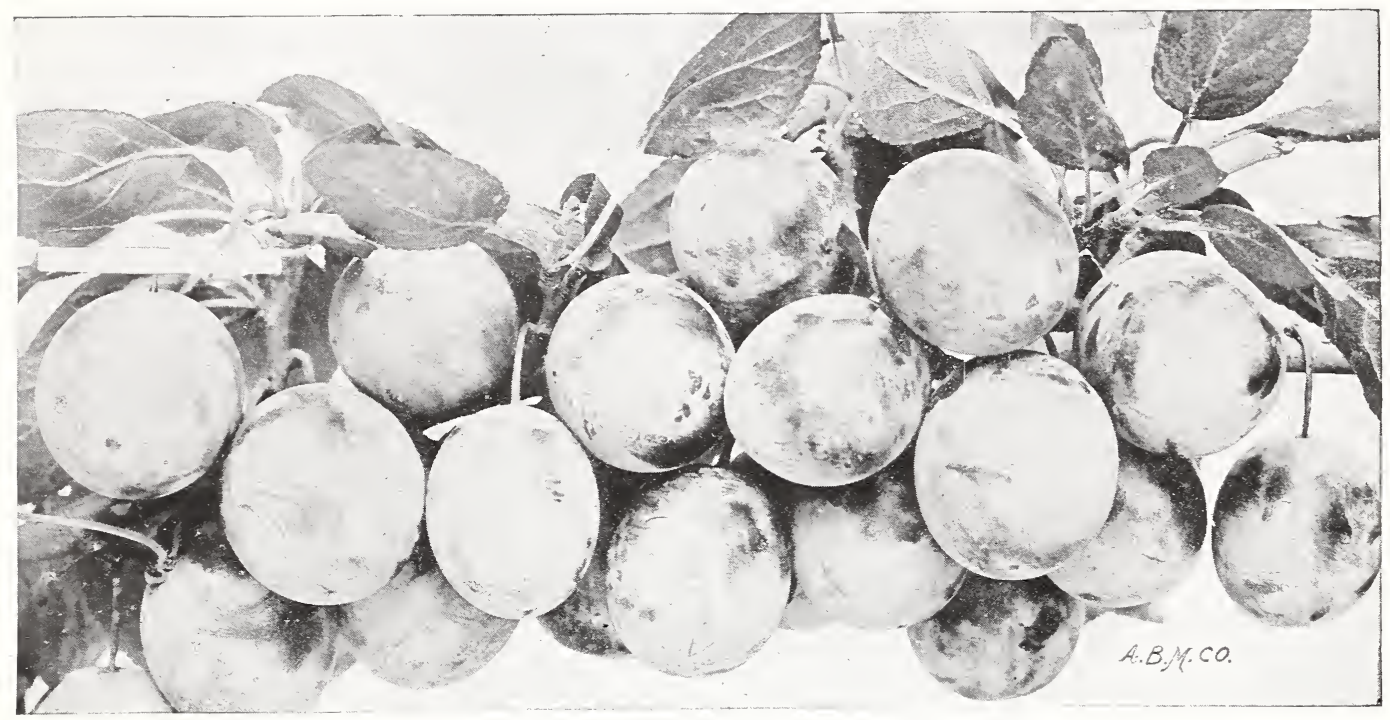

Plums.

\section{Plums}

The finest and most abundant crops are borne in clay loam soils. The varieties selected will do well in most sections of the Northwest.

Blue Damson. Fruit small, oval; skin dark purple, covered with blue bloom; much used for preserves.

Bradshaw. Large, dark red; flesh green, juicy, good; ripens first of September.

Burbank (Japan). Tree a vigorous grower; early and very heary bearer; fruit very large; yellowish ground, with red cheek in the sun; flesh yellow, firm and very sweet when full ripe; extremely small pit, which clings. Niddle of June.

Coe's Golden Drop. Large and handsome; light yellow, firm, rich and sweet. Sept.

Formosa. Unusually handsome fruit, very uniform in size, averaging about six by eight inches in circumference, shading from light to deep cherry in color, sweet, delicious, de- lightful apricot flavor; nearly freestone. Tree thrifty grower, large, thick, healthy, light green foliage. "Best Plum in existence" at the present time.

Green Gage. A medium small greenish yellow Plum of high quality. One of the best of American sorts. Midseason.

Peach Plum. Fruit of the largest size and earliest to ripen; regularly formed, roundish; skin red, dotted with a blue bloom; flesh greenish yellow; becomes tinged with red at maturity; a rich, brisk flavor; the leading market variety. Middle of July.

Satsuma. Japanese variety, blood red flesh small pit, pleasant flaror. Hardy.

Yellow Egg. I Largest size; skin yellow; flesh yellow, very sweet; first class for canning and a good bearer. September.

\section{Prunes}

The Prune is very similar to the plum, requiring same soil and planting treatment. Generally used for drying; also valuable for shipping in fresh state.

Coates 1418: Date Prune; Improved French Prune. Sweeter. larger than French; fine for drying. Reddish purple, juicy.

Hungarian. Largest size, with a beautiful bright red, making it one of the best for marketing; not good for drying. September.

Italian (Fellenberg). Medium to large size, oval, dark purple; flesh juicy, sweet and delicious; a standard drying and shipping variety. September.
Silver Prune. Large size and sweet; a good dryer; ripens rather late for northern climates. October.

Sugar Prune. An extremely early Prune, ripens August 1st; cures superbly rich, with a yellow flesh, tender and rich in sugar juice; fruit large, skin very tender, at first of a light purple, tinted with green, changing at maturity to dark purple, covered with a thick white bloom. Tree a vigorous grower and very productive.

Tragedy. Medium size; skin dark purple; flesh of yellowish green, very rich and sweet; frees readily from pit. Its early ripening (in July) makes it a valuable shipper. 


\section{Nectarines}

In growth, habit, treatment and soils precisely similar to the peach. Valuable for dessert; smooth skin.

Farly Violet. Medium size, skin yellowish green, with a purplish cheek. Flesh melting, rich and highly flavored. July.

Boston. Medium; deep yellow, with a bright blush and deep mottlings of red; flesh yellow without any red at the stone; sweet, though not rich, with a pleasant and peculiar flavor. Freestone.

Humboldt. Large orange-vellow color, orange flesh. Better than Boston.

\section{Apricots}

This is one of the most beautiful of the stone fruits. A thrifty grower soon making a fine nead, producing an abundance of fruit. Requires practically same conditions and treatment as the peach.

Blenhoin. The fruit is above medium size, oval shaped, deep orange color. Flesh beautiful yellow, juicy, fine flavored. Extensively grown in California in all sections because of its fine quality and profitable returns.

Moorpark. Fruit large, roundish, about $2 \frac{1}{4}$ inches in diameter. Skin orange in the shade, but deep orange or brownish red in the sun. Flesh guite firm, bright orange, parting from the stone. Ripens early in August.

Peach Ipricot. One of the largest; fruit firm juicy, with a rich flavor; productive. Last of July.

Royal. A fine, large French variety; fruit roundish, large, oval, slightly compressed. Skin dull yellow with an orange cheek, very faintly tinged with red. Flesh pale orange, firm and juicy, with a rich, vinous flavor Ripens the latter part of July.

Tilton. Fruit large size, rich apricot color, with a flavor of the highest quality. As a result of its fruit buds putting out much later than other varieties it is said to bear immense crops every year, and is considered the most prolific of all apricots, either for canning or drying.

\section{Quinces}

This fruit is valuable for flavoring and preserving either alone or for its pleasant flavor if added to other fruits. Rather moist soils which are deep and rich give best results.

Champion. A prolific and constant bearer. Fruit large and of excellent flavor. Bears extremely young. Hardy.

Orange. Large, golden color. Excellent for preserves and flavoring.

Pineapple. Originated by Luther Burbank. Suggestive of the pineapple. Makes a superior jelly. Can be eaten raw and is said to cook as tender in five minutes as the best cooking apple; possessing a most exquisite and delicious flavor not equaled by any other Quince.

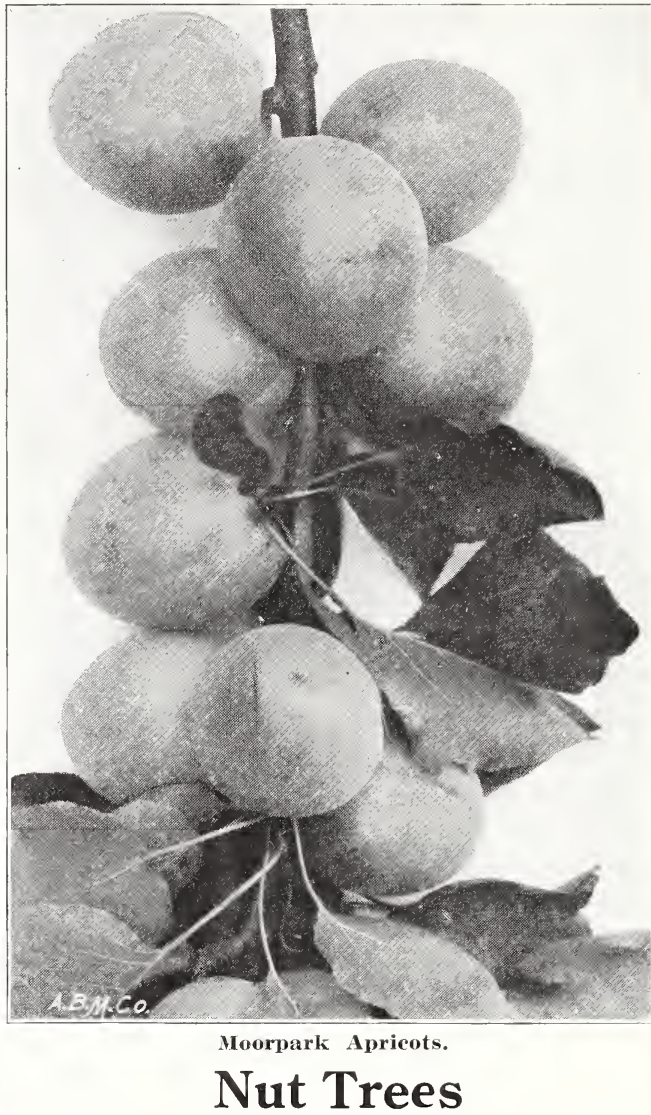

The planting of nuts of various kinds would prove profitable in many places unsuited to other purposes. Waste places and hillsides could be utilized and made to produce profit if planted to Walnuts, Chestnuts or Filberts. The better the soil, however, the greater the results.

\section{Chestnuts}

Spanish or Italian. A handsome round-headed tree, producing abundantly very large nuts that find a ready market at good prices. Not guite as sweet as the American Chestnuts. Tree is hardy with us.

\section{Walnuts}

Imerican Black. This valuable tree grows and succeeds well on this coast. Valuable for timber and nuts.

Butternut or White Walnut. A fine native tree, producing a large, longish nut, which is prized for its sweet, oily, nutritious kernel. Tree hardy.

\section{English Walnuts}

Trees begin to bear in about six years. This tree is propagated by grafting, budding, and from seed. The grafted tree is harder to grow and commands a higher price. An excellent nut is produced from trees grown from selected first generation nuts. The nuts we plant are from a choice strain of grafted varieties, growing in the nut districts of California.

Framquette Walnut. Nut very large and long: kernel full fleshed, sweet and rich; buds out late in the Spring, which enables it to escape the disastrous effects of late frosts. Tree a hardy, thrifty grower and abundant bearer. 


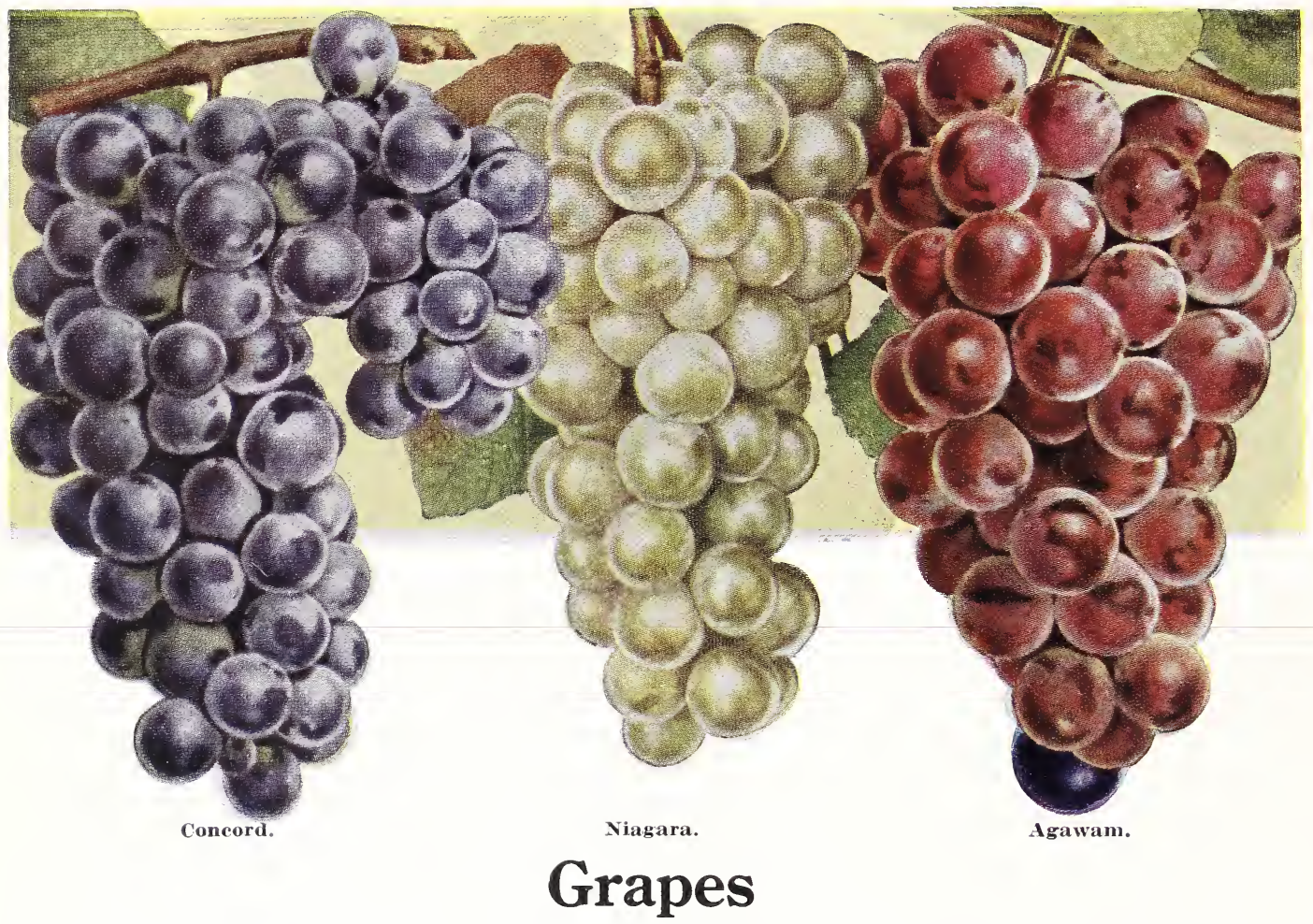

There are two distinct classes of the Grape; the American or hardy varieties, and the European, which usually require some Winter protection to insure a crop each season. A dry and warm soil is considered best for the Grape and if deep and rich will bring it to perfection.

\section{American Varieties}

Agawam. Vine very vigorous, productive; bunch large, moderately compact, shouldered; berry large, roundish, dark red or maroon; flesh almost tender, juicy, vinous, rich, peculiar aromatic flavor. Especially adapted for arbor culture. Ripens with the Concord. We consider this the best of American varieties.

Concord. The well known standard variety, succeeds wherever Grapes will grow. Black, sweet, good. First of September.

Chasselas Musk. Berries round, amber colored, russety when ripe, strong delicious sweet musky flavor.

Campbell's Early. Strong grower, with large healthy foliage; productive; its keeping and shipping qualities are equalled by no other early Grape. Ripens with Moore's Early. Bunch and berry large, glossy black with blue bloom; sweet and juicy; seeds few and small; part readily from the pulp. Stands at the head of early black Grapes for quality.

Delaware. Bunches compact; berries rather small, round, skin thin, of a beautiful light red; exceedingly sweet. September.

Moore's Early. Bunch large; berry large; round, with heavy blue bloom; vine exceedingly hardy. Its earliness makes it desirable for an early market. Its hardiness particularly adapts it to Canada and northern portions of the United States.

Niagara. Occupies the same position among the white varieties as Concord among the black. A profitable market sort. Bunch and berries large, greenish white, changing to pale yellow when fully ripe. Skin thin; quality much like Concord.
Worden. This new variety is a seedling of the Concord, which it greatly resembles in appearance and flavor, but the berries are larger. The fruit is said to be better flavored and ripens several days earlier.

\section{European Varieties}

Black Prince. Very large, oval; bunches medium; flesh firm, with a rich delicious flavor, and highly esteemed as a market variety. September.

Flame 'Tokay. Bunches very large and moderately compact; berries large, skin thick, pale red, covered with bloom; flesh firm, sweet; an old standard variety, always demands a good price in the markets, and as a table Grape, more extensively planted than any other variety. October.

Muscat of Alexander. Bunches large, long and loose; berries large, slightly oval, pale amber when ripe, covered with a thin, white bloom; flesh firm, brittle, exceedingly sweet and rich; fine flavored; the variety most extensively planted for raisins. September.

White Sweetwater. Vines hardy; fruit rich and sweet. Very much resembles the Royal Muscadine but the berries are not so compact on the bunch. First of August. 


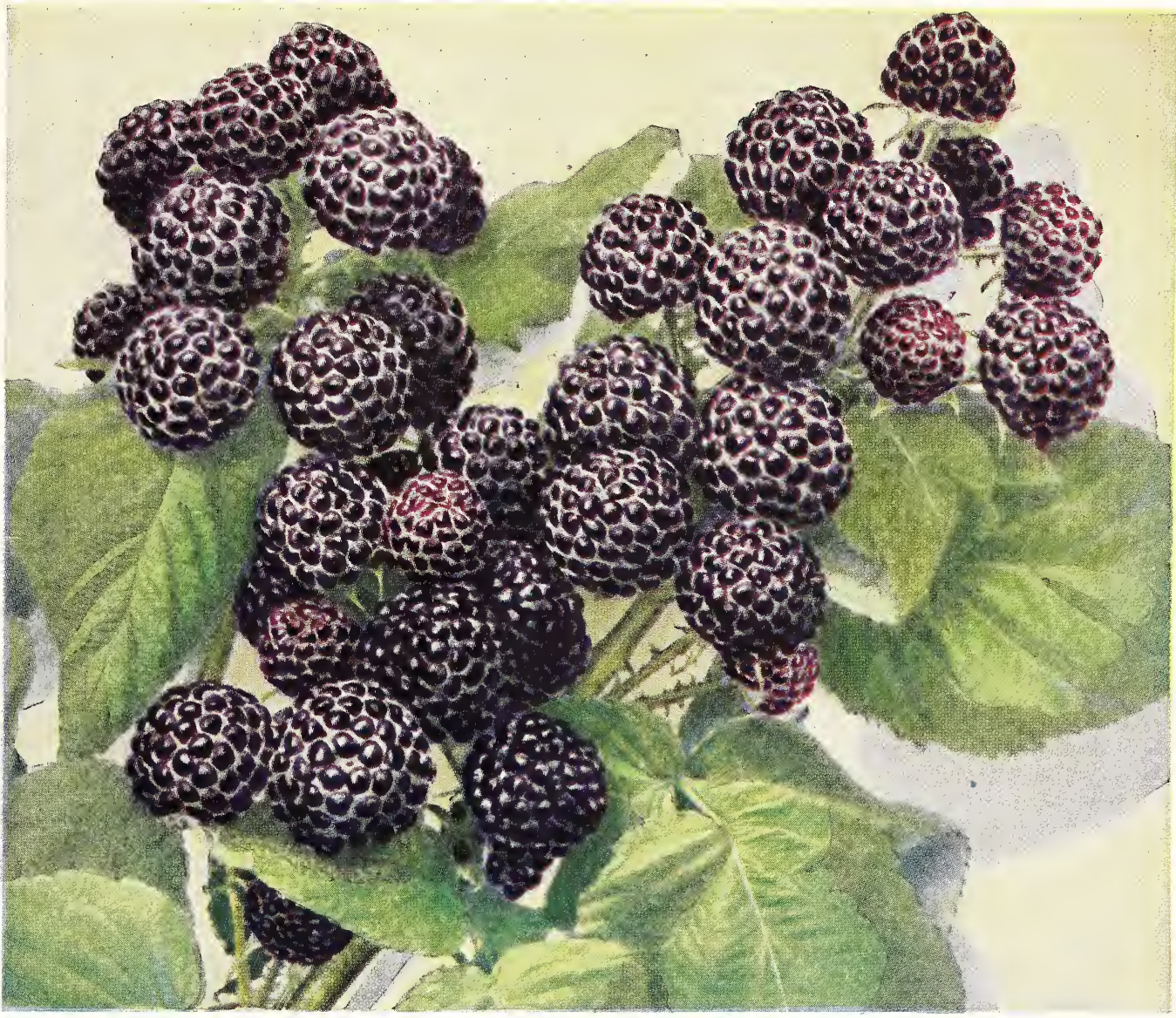

Cumberland Blackeaps.

\section{Raspberries}

Cumberland. The largest Black Raspberry known. In hardiness and productiveness it is unexcelled by any other variety.

Cuthbert. Canes tall, vigorous and very productive; berries large, conical, rich crimson color; best quality; good shipper. The canes are very thrifty growers, upright in shape, light yellow color and generally quite hardy.

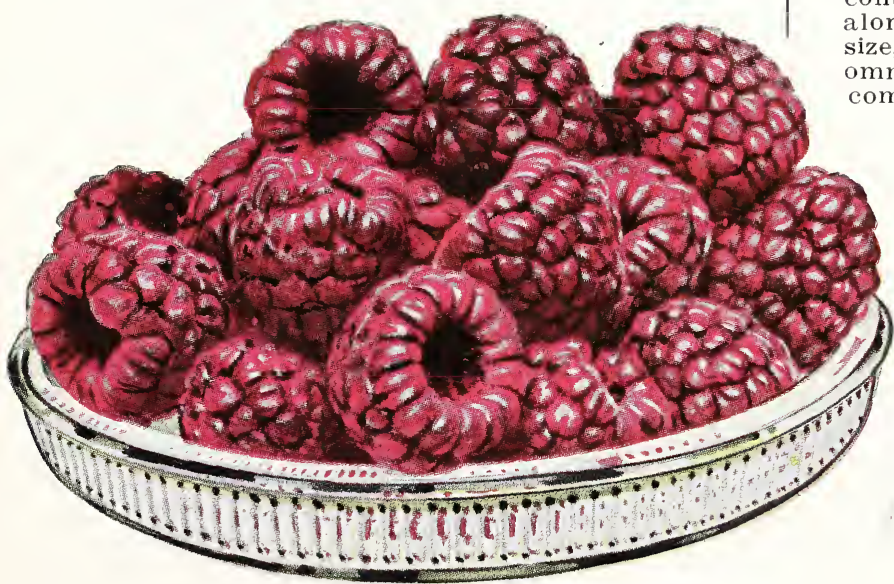

Cuthbert Red Raspberries.
Golden Queen. A beautiful, large, golden yellow berry; seedling of the Cuthbert and surpassing that variety in size, beauty, quality and adaptability.

St. Regis. The wonderful everbearing Raspberry. Should be grown in every home garden. This Raspberry will give you a crop of berries from July till frost. It begins ripening with the earliest red Raspberries and continues bearing on the young canes all along till Fall. Berries bright crimson, large size, sweet, rich Raspberry flavor. We recmmend it for home gardens but not as a commercial variety.

\section{Currants}

Fay's Prolific. The berry is fully equal to Cherry Currant, while the flavor is much superior. The stems are double the length on an average, and the fruit hangs on well, never dropping as in other Currants. Surpasses any other variety ever introduced.

Perfection. Berries are a beautiful bright red and larger than Fay's Prolific. In quality it is said to be superior to anything in the market today; rich, mild, sub-acid flavor, with plenty of pulp and few seeds, clusters are large and size of berry is maintained to the end. 


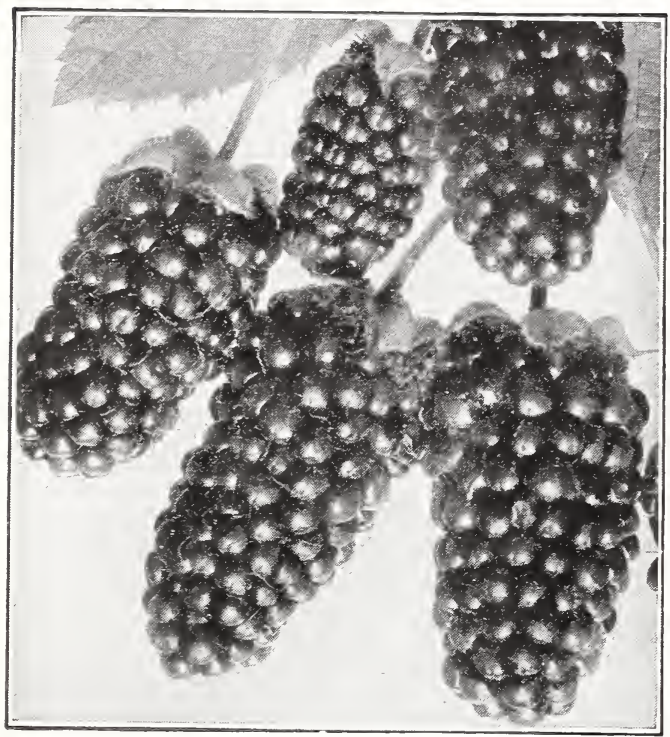

Lucretia Dewberries.

\section{Dewberry}

Lucretia. One of the low-growing, trailing Blackberries. In earliness, size and quality it equals any of the tall-growing sorts. The plant is extremely hardy, healthy and productive. Fruit is of the largest size, soft. sweet, luscious throughout, with no hard core. Very valuable.

\section{Gooseberries}

The best soil for it is a deep strong loam, well enriched. For the Gooseberry regular and liberal pruning is very essential.

Oregon Champion. Larse, skin light green. Flesh very sweet, juicy, excelient flavor; very prolific bearer and will not mildew.

\section{Mulberries}

This tree should be planted in every garden. A hardy deciduous tree thriving in a great variety of soils.

Rusian. A very hardy, rapid grower. Fruit small but produced in abundance. A valuable tree for windbreaks.

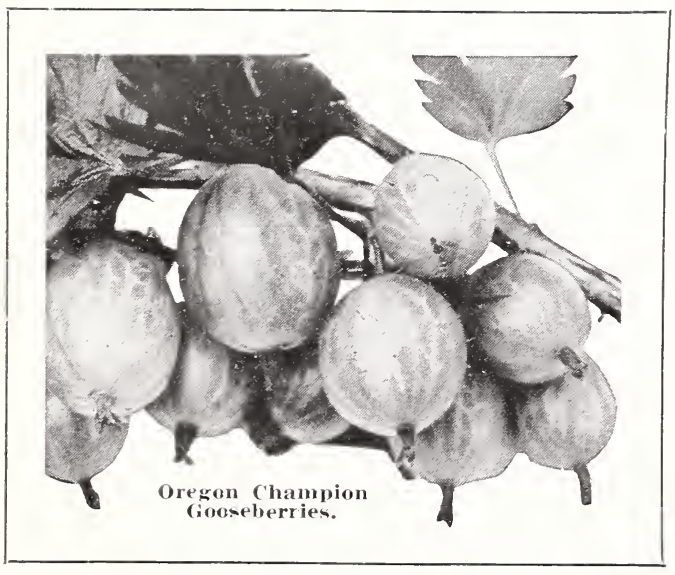

\section{Blackberries}

Evergreen. Heary grower, berries large; black, sweet, delicious; long season. Good for trellis,

Himalaya Giant. Vigorous grower, must be trellised; fruit large, black, abundant bearer, juicy, small seed and core, heary yielder, distinct flavor.

Lawton. Large, black, sweet. Very productive. One of the best.

Mammoth. Grows entirely unlike any other Blackberry plant known. It is a rampant grower, trailing on the sround, and under farorable conditions will grow twenty feet in a season; the canes are large, of deep red color when exposed in the sun; productive and exceedingly early, ripening three weeks before other cultivated kinds; fruit enormous specimens; seeds small, core small, soft; in size and flavor said to surpass all other varieties of Blackberries. Vines not very hardy.

Mersereau. Early, mammoth, ironclad Blackberry. In quality it is exceptionally sweet, rich, melting and luscious, being without core; the seedy character of the snyder and most other sorts is noticeably absent.

\section{Hybrids}

Logan (Raspberry-Blackberry). Fruit size of large Blackberries, same form and shape; color dark, bright red; partakes of the flavors of both Blackberry and Raspberry; mild, pleasant, vinous, excellent for table and for canning, jelly, etc. Seeds few and small.

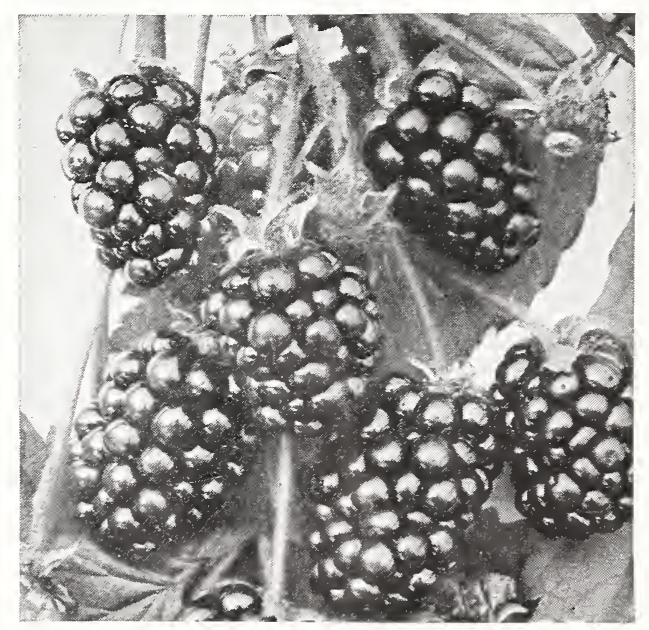

Mersereau Blackberries.

\section{Rhubarb or Pie Plant}

Fhubarb, with its flavor of the springtime, is a valuable aid to the action of the gastric juice, adds novelty to the bill of fare, has the good points of a fruit, and combines deliciously as a dessert or a conserve.

Mammoth Rhubarb. Early, very tender, and has mild, sub-acid flavor, not "stringy" or tough. The plant is large, and for pies or other culinary purposes, a favorite.

\section{Horseradish}

Requires deep, fertile soil for best results; roots pungent, used for pickling and flaroring. 


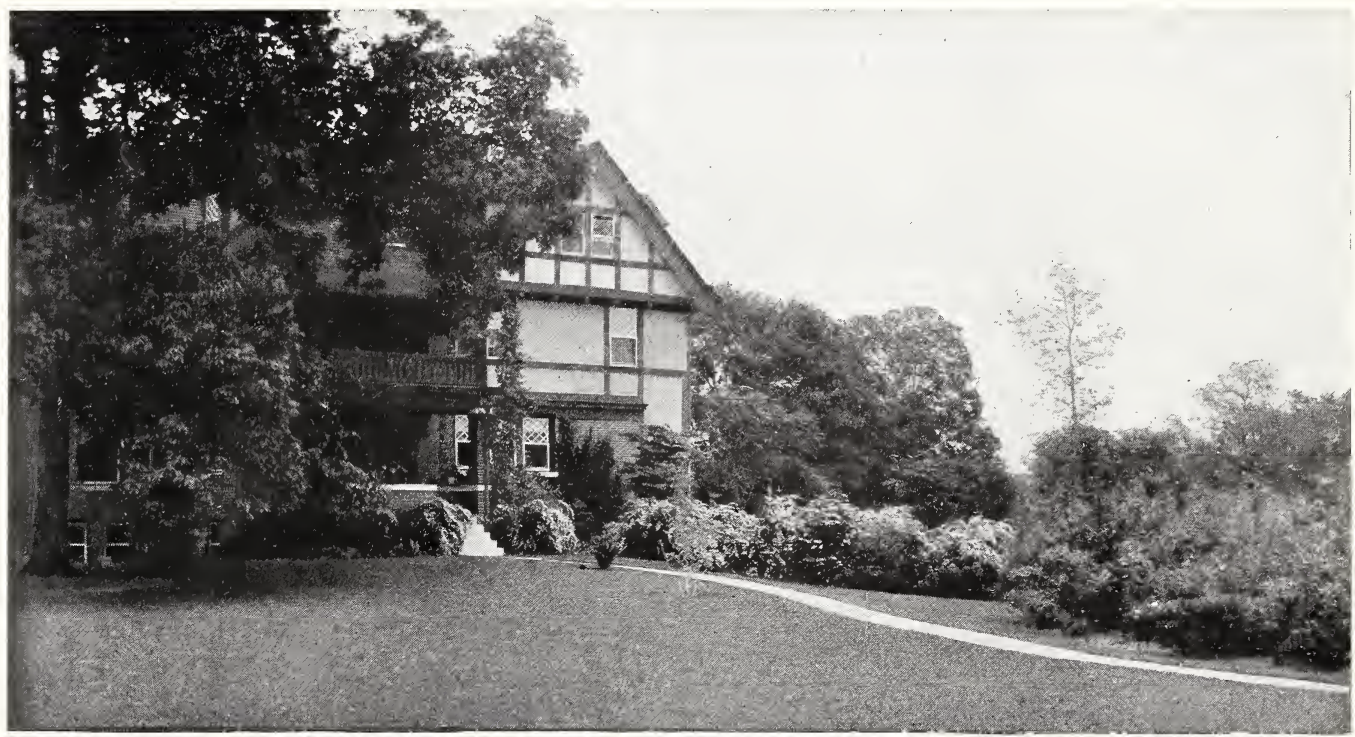

The Judicious Use of Shrubs Transforms Grounds into a Pleasing Landscape.

\section{Ornamental Department}

\section{Shade and Ornamental Trees, Shrubs, Plants, Vines and Roses}

Much of the time and activities of the home builder throughout the Northwest has been spent in the development of that which will furnish substantial cash returns in the way of setting and care of commercial orchard fruits, etc. This has been done at the expense of the esthetical side of life, as many of our home grounds and public parks testify. A very small outlay of time and money, with a careful selection of suitable shade and ornamental trees and shrubbery, will add beauty and comfort to the home and enhallce its value commercially many fold. Many undesirable and barren spaces adjacent to many of our towns could be made into cool retreats by planting trees and shrubs. In planting shade trees it should be done with the thought that they will need as much care and attention for a few years at least as our orchards. Quicker and more satisfactory results will thus be obtained.

Select well shaped, nursery grown trees in preference to forest grown trees, or cheap stunted nursery stock. The wide range in selection offered makes it easy to secure trees for all purposes. The large number of varieties, habits of growth, variations in foliage and floral effects may be used very advantageously in beautifying the garden or the landscape.

Our trees are all select specimens and such as are found to be adapted to the conditions which obtain generally throughout the Pacific Northwest.

We will be glad to send to any one interested in landscaping, special illustrated pamphlets that are very helpful in planning home grounds. Free on application.

\section{Birch - Betula}

European White (Betula alba). A graceful tree, with silvery bark and slender branches. Vigorous grower, with rather pendulous branches. Beautiful tree for either lawn or street planting.

\section{Catalpa}

Westem Catalpa (Speciosa). A very effective, tropical-looking tree, of rapid, spreading growth. Heart-shaped, broad green leaves. Blooms in July, showy and quite fragrant. Good shade and ornamental tree. Adapted to dry conditions.

Umbrella Catalpa (Bignonoides nana). Makes a dense, round head of heart-shaped leaves. Does not bloom. Fine for parks or street planting.

\section{Crab - Malus}

Bechtel's Double-Flowering (Ioensis Bechteli). Makes a beautiful, medium sized ornamental tree of great beauty. Perfectly hardy, succeeds well in most soils. When in bloom in early Spring this tree presents the appearance of being covered with perfectly double, small pink roses, of delicious fragrance. The only sweet scented double Crab; blooms quite young.

\section{Horse-chestnut - Aesculus}

Red-Flowering (Rubicunda) Not so rapid or as fine growing as the White. Foliage of deep green. Blossoms later with showy red flowers.

White-Flowering (Hippocastanum). A very beautiful, well known tree, with round, dense head, green foliage and an abundance of showy flowers in early Spring. Readily transplanted, hardy and succeeds well on a variety of soils. 


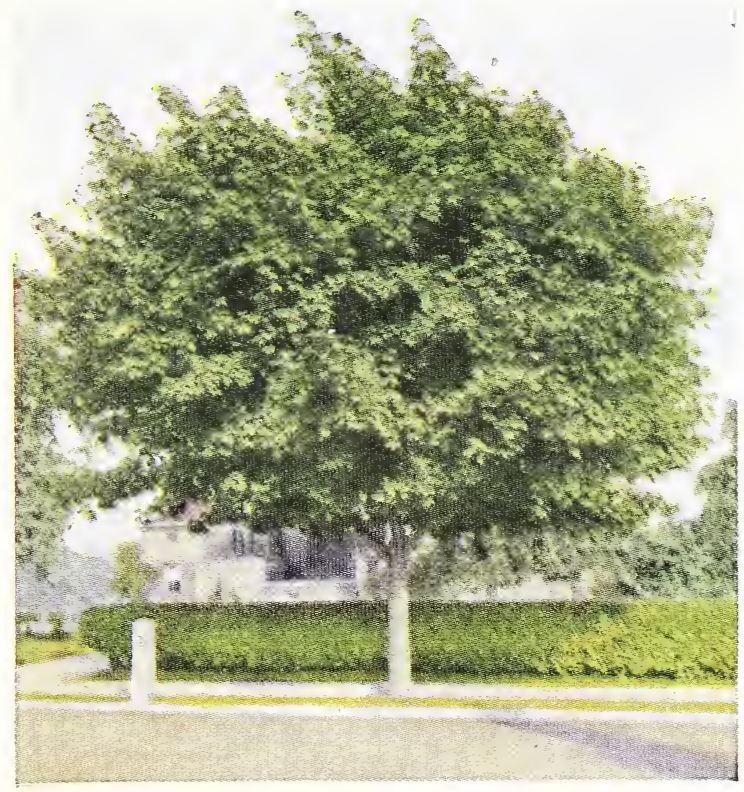

Norway Maple.

\section{Hawthorn - Crataegus}

Paul's Double Scarlet (Monogyna Pauli). Flowers large, deep carmine scarlet, very showy and slightly perfumed. The Thorns justly deserve to be classed among the most beautiful flowering trees. Thrives in dry soil.

\section{Locust - Robinia}

Black Iocust (Pseudoacacia). A very rapid growing tree, covered in June with sweet scented, white flowers. Valuable as a quick growing shade tree and for its hard wood.

Umbrella Locust, Globe-Headed Locust (Umbraculifolia). Forms a round head, without trimming, dark green color, dense foliage. Fine for parkings or specimens. Does not bloom, henre a cleaner tree than the ordinary Locust.

\section{Mountain Ash - Sorbus}

European (Aucuparia). A fine, hardy shade tree and ornamental tree; head dense and regular. Covered from July till midwinter with large clusters of bright red berries.

\section{Maples - Acer}

Ash-Leaved or Box Elder (Negundo). A rapid growing variety with spreading head. Succeeds well in dry soil where other varieties do not thrive. Well known variety.

Norway (Platanoides). A native of Europe. Its large, compact habit, broad, deep green, shining foliage and its vigorous growth, render it a desirable tree.

Silver or Soft Maple (Dasycarpum). This rapid growing tree is being largely planted in many places. It is a clean tree of great beauty and hardiness. One of the best for streets. parks and lawns.

Schwedler's Nomwa Maple (Schwedleri). A beautiful rariety with young shoots and leaves of a bright purplish or crimson color, which changes to purplish green in the older leaves. One of the most valuable.
Silver Variegated (Argenta). This we consider one of the most attractive small ornamental trees grown; so much of the leaf is variegated that at a short distance it has the appearance of the whole leaf being a silvery white. Hardy as the Ash Leaf Maple.

\section{Plane Tree - Platanus}

European Plane or Sycamore (Platanus orientalis). Superb tree of gigantic proportions; dense foliage of bright green leaves, generally five-lobed. As a shade tree cannot be excelled. Genera favorite for planting in parks, avenues, and streets. Rapíd grower.

\section{Poplar - Populus}

Carolina Poplar (Populus carolina). A vigorous, healthy tree of rapid growth pyramidal-shaped head, large, glossy leaves; valuable for park or street planting. Succeeds well everywhere.

Canadian Poplar or Sudden Saw Log. Similar to Carolina Poplar; very rapid in growth, spreading. Good for windbreaks.

\section{Weeping Trees}

Birch, Cut-Leaf Weeping (Betula alba laciniata pendula). Beyond question one of the most popular and elegant of all weeping, pendulous trees. Its tall, slender, vet vigorous growth, graceful drooping habit, silvery white bark and delicately cut foliage, presents a combination of attractive characteristics rarely met with in a single tree.

Willow, Wisconsin Weeping (Salix babylonica dolorosa). A beautiful tree with straggling, weeping branches. Makes a fine tree for the lawn or background.

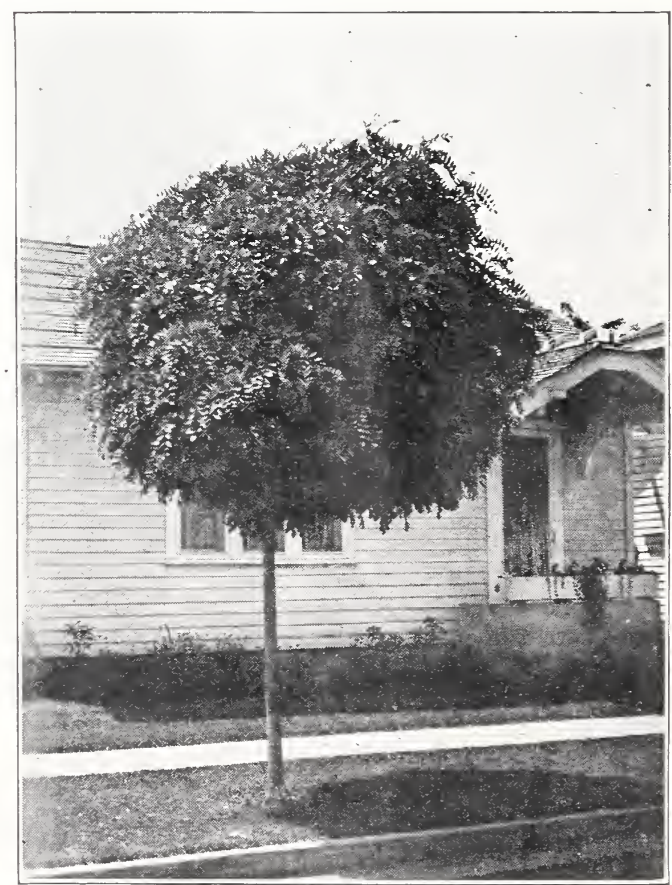

Umbrella or Globe-Headed Locust. 


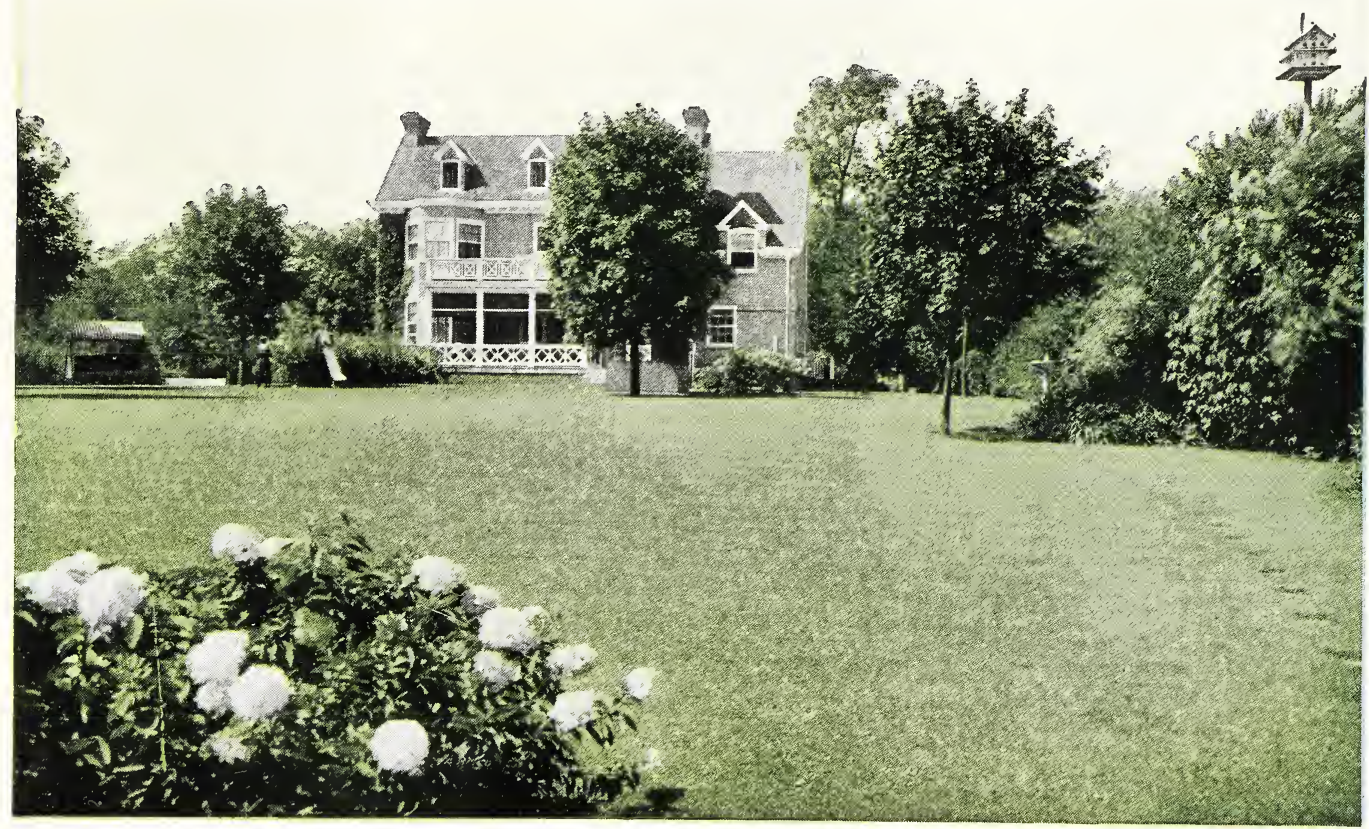

\section{Hardy Flowering Shrubs}

The permanent value and beauty of deciduous shrubs was never better understood and appreciated than at the present time. The charm and grace they lend to the home grounds is invaluable, and, if judicious selection is made, it is possible to have a continuous succession of bloom from early in April, when the Forsythia displays its brilliant golden flowers to welcome the returning birds, to the days when the frost again nips the flowers of the very latest to bloom. In our descriptions we endeavor to indicate the height of the bush at maturity, the time of its blooming, in this latitude, and the color of its flowers.

\section{Althea - Hibiscus}

A showy and beautiful flowering shrub. The flowers are large size, very double and full of brilliant colors, beginning to bloom when transplanted and continues to bloom every year from midsummer until frost.

Admiral Dewey. Semi-double, violet-blue.

- Elegantissima. Double white, shaded with rose.

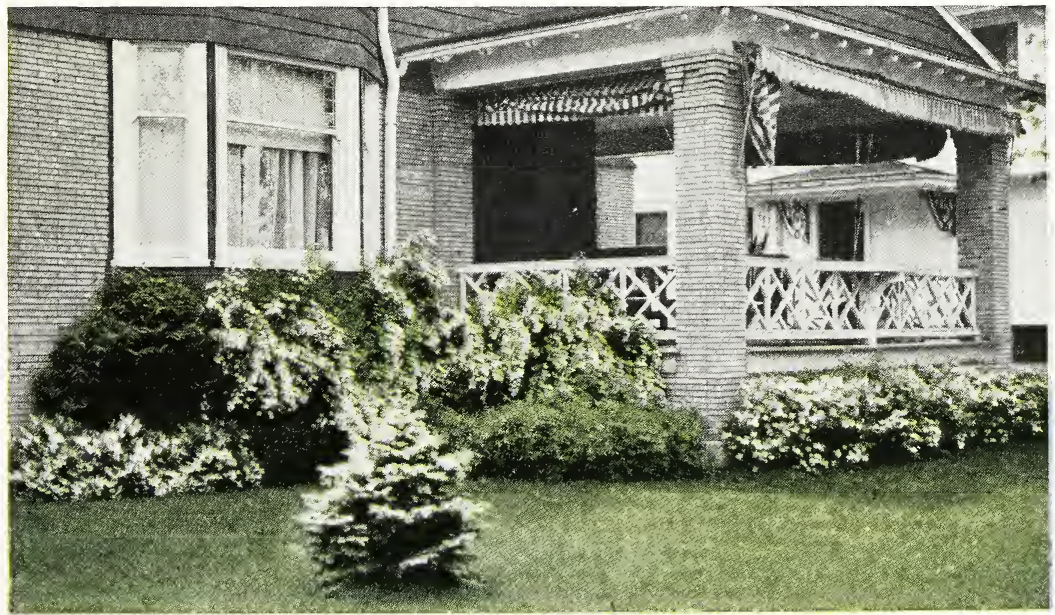

Rubra plena. Double red Althea. Clear color. One of the best.

Variegata fl. pl. Variegated-leaved, double purple flowers. Foliage marked with light yellow. One of the finest variegated-leaf shrubs.

\section{Buddleia - Butterfly Bush}

Davidi magnifica. A $n$ p right, strong growing bush, with long spikes of beautiful lilac colored flowers. Shrub semi-herbaceous. Dies down in some latitudes. Should be given some Winter protection.

\section{Calycanthus - Butneria}

Floridus. Sweet scented shrub. Flowers purple, double and deliciously scented. Remains in bloom a long time. 


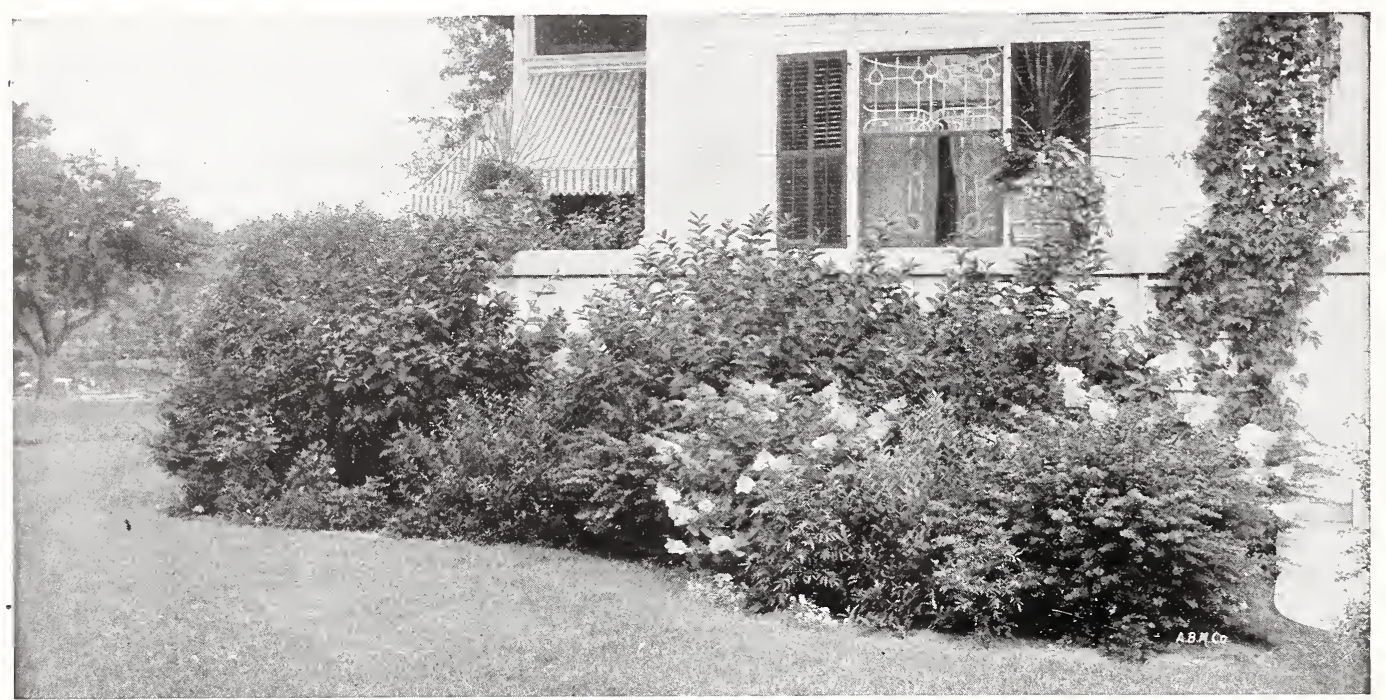

A Well Planned Foundation Planting.

\section{Deutzia}

Crenata. Flowers double white, tinged with pink. Blooms in June. One of the fine hardy shrubs.

Gracilis. Fine hardy shrub, forming round, compact mass of white in June. Makes pretty hedge.

Lemoine. Large, white flowers. June. Graceful.

Scabra (Pride of Rochester). Large-flowered, tinged pink. Double. Vigorous. June.

\section{Elder - Sambucus}

Aurea. Golden yellow foliage. One of the best golden-leaved shrubs.

\section{Forsythia - Golden Bell}

Fortumei. Good habit. Branches arching; vigorous grower.

Intermedia. Flowers bright golden. Foliage glossy green.

Viridissima. Most vigorous, has green bark and thick dark green leaves. Last to flower.

Suspensa. Graceful drooping habit. Excellent for massing or banks.

\section{Lonicera - Honeysuckle}

Tatarica rosea (Bush Honeysuckle). Pink flowers which contrast beautifully with foliage.

Tatarica alba. Forms a high bush with creamy white, fragrant flowers.

Tatarica grandiflora rubra. Very vigorous and produces bright red flowers striped with white in June.

\section{Hydrangea}

Peegee (Paniculata grandiflora). Generally considered the most valuable and ornamental shrub in existence. Bushy, robust, free bloomer with immense close panicles of flat, snow-white flowers of gigantic size. No other shrub makes such a show on the lawn or is so universally admired. Hardy any place.

Arborescens. Foliage green, bluish beneath. Very attractive.

\section{Kerria}

Japonica. Green branched shrub, conspicuous in Winter; nicely cut leaves, abundant yellow flowers from June to October.

Flore pleno. Handsome double yellow roseshaped flowers.

\section{Lilac - Syringa}

Priple (Vulgare). The common purple species and one of the best.

White (Alba). Flowers pure white. Very fragrant and beautiful.

Persian (Persica purpurea). More slender growth than common variety. Purple flowers in immense spikes.

Persian White (Alba). Similar to above except in color which is white.

\section{Budded Lilacs :}

Alphonse Lavallee. Double. Blue shaded violet.

Belle de Nancy. Double. Very large. Color satiny rose, with white toward center.

Charles $\mathbf{x}$. Strong, rapid grower, leaves dark and shiny, trusses large and rather loose. Color reddish purple.

Ludwig Spaeth. Flowers large, single, dark purplish red. Trusses very long.

Mme. Casimir-Perier. Double white. Superb.

Jacques Calot. Large panicles of rosy pink flowers, individual flowers unusually large. Distinet.

President Grevy. A grand sort. Flowers double. Beautiful blue. Heavy truss. One of the finest.

\section{Mahonia - Holly Grape}

Oregon Holly Grape (Aquifolium). Bushy shrub, leaves at first fresh green, tinged purple. Assume beautiful red and bronze tints in Autumn, which are retained throughout the Winter. Yellow flowers in Spring followed by blue berries. 


\section{Philadelphus - Mock Orange}

Coronarius (Common Mock Orange). Flowers pure white and very fragrant in May and June in profusion.

Virginalis. Intensely fragrant, long season, immense anemone-shaped, ivory-white flowers. First quality.

\section{Plum - Prunus}

Triloba (Double-Flowering Plum). Vigorous growth; flowers semi-double, delicate pink, upward of an inch in diameter, thickly set on branches in May. Very attractive; choice specimen for planting on lawn.

Pissardi (Purple-Leaved Plum). Vigorous, upright growth. Foliage maroon-red. Very handsome from early spring to late Fall.

\section{Quince - Cydonia}

Japan Flowering (Japonica). Bright scarletcrimson flowers in great profusion in early Spring with bush covered with golden fruit. Hardy.

\section{Snowberry - Symphoricarpos}

Racemosms. Much valued for its white berries, borne abundantly in Autumn.

Vulgaris. Fied fruit. Not so large as the white but more abundant. Graceful habit.

\section{Snowball - Viburnum}

Conmon Snowball (Sterile). A well known shrub. Attains a height of eight to ten feet. Produces its flowers in large balls in May.

High Bush Cranberry (Opulus). Handsome and dense foliage. Flowers. white in drooping white cymes followed by brilliant scarlet fruit in showy pendulous bunches that remain on the plant all Winter.

\section{Spireas}

Anthony Waterer. A new crimson-flowered variety which is in our estimation one of the best dwarf, flowering plants. It makes a low, compact bush, two to three feet high and is covered from spring until late Fall with large heads of deep crimson flowers. Perfectly hardy.

Opulifolia aurea. An exceptionally fine variety, not only for its floral display but for the golden foliage. Creamy white flowers produced in clusters all along the stem. Of great beauty.

Prumifolia. Very beautiful. Its flowers are double and like white daisies. Blooms in May.

Thunbergi. Graceful. The first to bloom in early Spring. Branches slender and drooping; small bright green leaves. Pure white flowers. Dwarf.

Van Houttei. It is a beautiful ornament for the lawn at any season, but when in bloom it is a complete fountain of white flowers, the foliage hardly showing. Perfectly hardy.

\section{Weigela}

Candida. A vigorous, erect grower; flowers pure white, borne all through the Summer months.

Eva Rathke. Remarkably free bloomer. Flowers distinct in color, being rich reddish purple, different from other sorts. Excellent.

Nana foliis variegata. Variegated leaf. Dwarf; clearly defined silver variegated leaves. Flowers nearly white. One of the best.

Rosea. Flowers of good size, delicately blushed rosy pink. Blooms in June and July.

\section{Yucca}

Filamentosa (Adam's Needle: Bear Grass) A hardy evergreen plant, with long, narrow leaves that are bright green the whole year. Flowers cleamy white, bell-shaped, produced in long spikes, three to four feet high. Easy to grow and does well in any climate.

\section{Evergreens}

Evergreens are very desirable, but rather difficult to transplant. They should be subjected to as little exposure as possible, set with care and shaded the first few months after transplanting. The numbers after the name of the variety indicate the usual height of growth.

\section{Thuya Occidentalis - American Arbor-Vitae}

Compacta (Parsons' Arbor-Vitae). $2 \frac{1}{4}$ to 4 ft. Almost globe-shaped; bright green; useful for formal or foundation planting.

Elegantissima (Golden Tipped Arbor-Vitae). 10 to $15 \mathrm{ft}$. Branches tipped with yellow, with rich, lustrous green.

Globosa (Globe Arbor-Vitae). $2 \frac{1}{2}$ to $3 \mathrm{ft}$. Natural globe shape.

Hoveyi (Hovey Arbor-Vitae). 3 to $4 \mathrm{ft}$. Oval in shape, nearly as broad as high, bright green foliage.

Pyramidalis (Pyramidal Arbor-Vitae). 15 to $30 \mathrm{ft}$ Retains its bright green color during the Winter. Narrow, columnar shape. Splendid for accents or formal planting.

Rosenthali (Rosenthal Arbor-Vitae). 6 to 10 ft. Dense, rugged, columnar form. Slow grower.

\section{Thuya Orientalis - Oriental Arbor-Vitae}

Amrea nana (Berckman's Golden Arbor-Vitae). $2 \frac{1}{2}$ to $3 \mathrm{ft}$. Fine for dwarf planting, compact, roundish form, warm, golden yellow foliage. Good for formal work or edging.

\section{Juniper}

Hibernica (Irish Juniper). 7 to $8 \mathrm{ft}$. A very narrow pyramid. Useful for its spirelike effect.

Pfitzeriana (Pfitzer Juniper). 5 to $6 \mathrm{ft}$. Broad, bushy habit, gray green foliage, giving feathery appearance. A most adaptable, hardy evergreen, highly recommended.

\section{Picea - Spruce}

Excelsa (Norway Spruce). 50 to $75 \mathrm{ft}$. Has dark green foliage and grows rapidly. Makes a good windbreak; also lends itself well to trimmed hedges. 


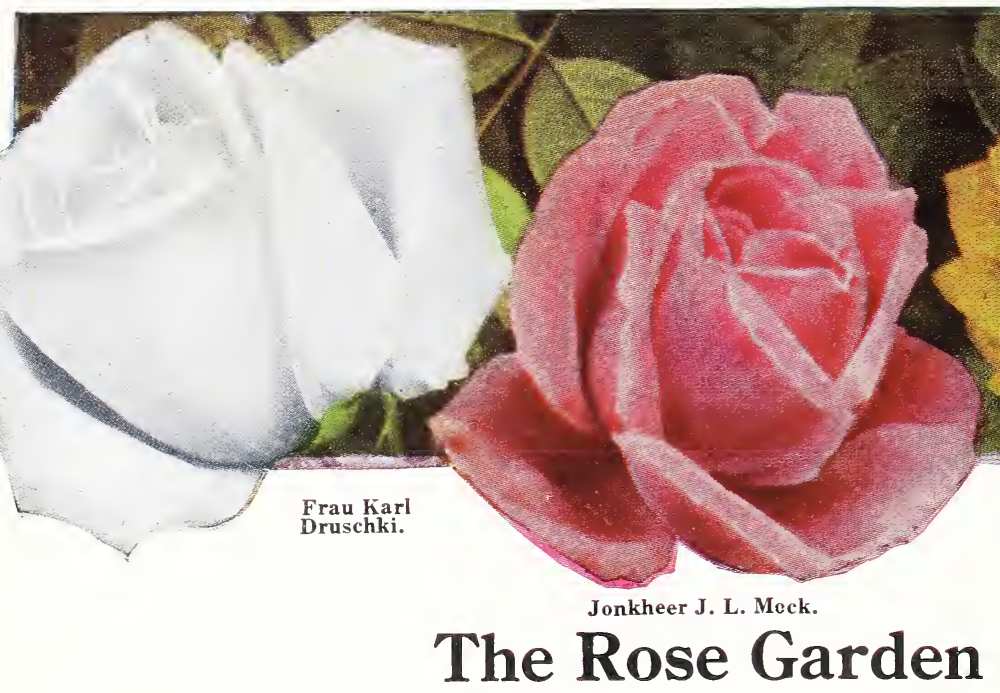

Perhaps no flower affords such delightsome results as the Rose. The Pacific Northwest seems peculiarly adapted to its successful culture, and it responds to the gentle touch of the lowly in bumble abodes as well as being a joy in the rick man's rosary. It sends forth its beauty and gentle perfume to be enjoyed alike by the lofty and humble.

\section{How to Grow Roses}

Location of Beds. Roses should be planted where they will be open to sunlight for at least half of each day. In locating beds, avoid trees, shrubbery and shady sides of buildings and fences. This will lessen the danger from insects and diseases.

Soil. Any good garden soil, which will grow good vegetables, will grow with proper fertilization, fine Roses. The ideal soil is a clay loam of sufficient porosity to permit of ready drainage.

Preparation of Beds. The beds should not be so large that the Roses cannot be reached without treading among them. Long, narrow beds, with one continuous row of plants, are preferable. Spade the soil to a good depth, mixing in well-rotted stable manure as you do so. Cow manure is considered the best, though well-rotted horse manure will do. Bone meal is excellent.

Planting. Nost varieties should be planted about $2 \frac{1}{2}$ feet apart, when the soil is in a nice. mellow condition. Spread the roots out well and press the soil down firmly. Plant slightly deeper than previously grown and give one good watering if weather is warm and dry.

Watering. Most people water their Roses too much. Once a week is often enough and that early in the morning. Keep the soil mulched or cultivated around the bushes to prevent baking.

Mulching and Protection. Only the tenderest varieties need any protection in this country. This can be be supplied by mulching the soil around the plants with a heavy application of cow manure, which should be spaded in the following Spring. All plants should have this mulching.

Pruning. Field grown dormant Roses should be cut back severely when first set out. Subsequent pruning should be attended to in late Winter and early Spring, when all dead and weak growth should be removed entirely and the strong, live canes shortened back to one or two feet in length, according to the growth of the previous season. It may be accepted as a general rule that weak growth should be pruned severely and strong ones sparingly. Climbing Roses should not be cut back any more than is necessary to keep the plant in a shapely appearance.

Best Time for Planting. No question is asked more frequently than "when is the best time to plant Roses." Our dormant field-grown Roses can be planted any time that the soil can be worked, between October and April. Probably the best month is March. Most people plant in that month and with best results when the soil has warmed up with the increasing strength of the sun's rays.

\section{Diseases and Insects}

Healthy, vigorous, well cultivated Roses in well located beds are less liable to the ravages of insects and diseases than weak specimens of slender growth and poor vitality. Therefore, keep your Roses healthy by good cultivation. It is the indifferent, indolent grower whose Roses are the prey for insects, although the weather in certain seasons aggravates the troubles of a Rose grower considerably.

Mildew. This is a fungus disease, shown by the grayish, crinkled and mouldy appearance of the foliage, caused chiefly by cool nights and hot days. Remedy: Dust lightly over the foliage Flour of Sulphur on a warm, sunny day.

Black Spot. Another fungus disease, usually making its appearance on Hybrid and Hybrid Tea Roses late in the season. The black spots on the foliage cause same to turn yellow and drop off. Pick off affected leaves and spray with "Bordeaux Mixture." Spray also when dormant the following spring.

Aphis or Green Fly. A little sucking, green insect, which sometimes gathers in countless numbers upon the new growth. Steep tobacco stems or leaves in water over night and apply with a spray pump or whisk broom. Warm soapsuds is also effective.

We guarantee a square deal and satisfactory service to every customer. 


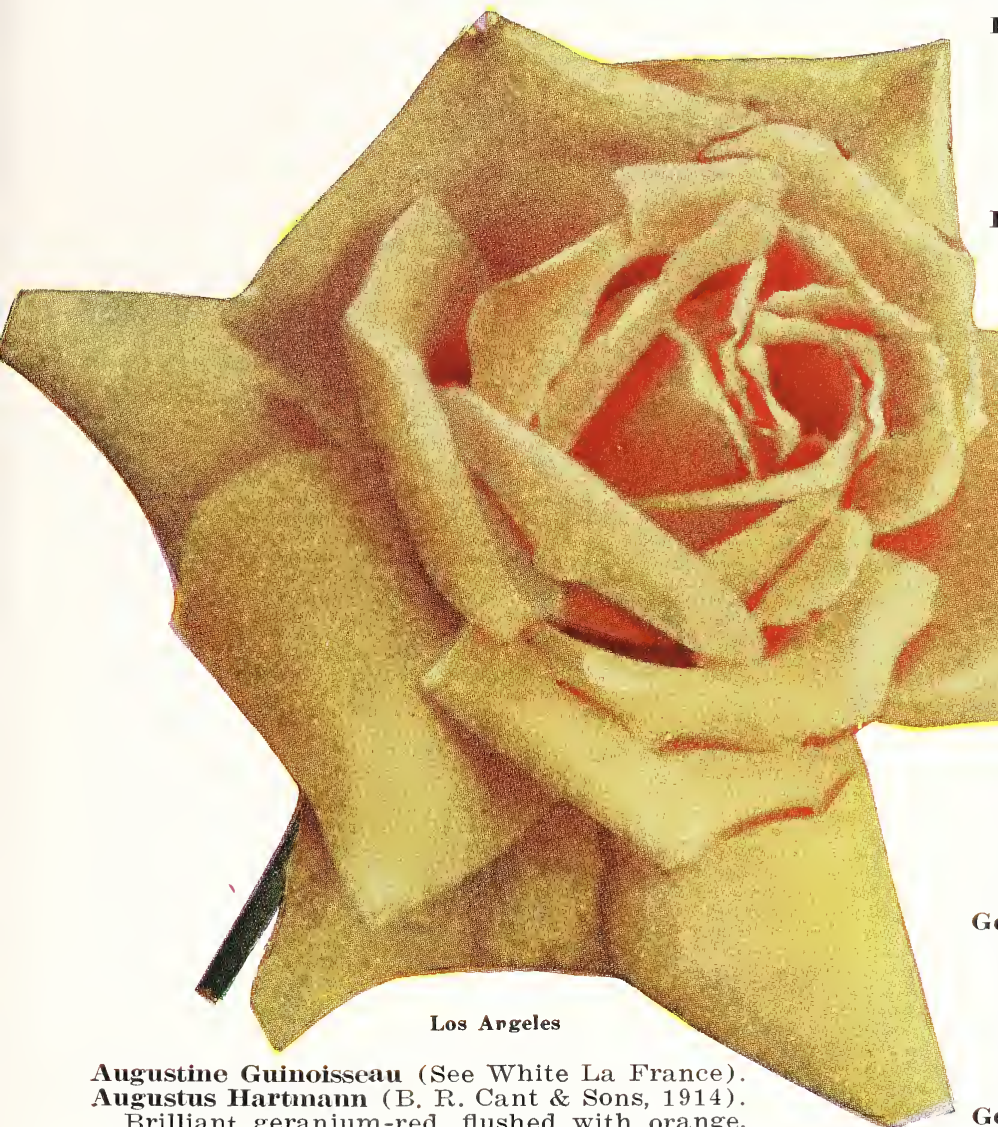

Augustus Hartmann (B. R. Cant \& Sons, 1914). Brilliant geranium-red, flushed with orange, sometimes bright cerise; flowers of large size and beautifully formed. The color is very striking. Awarded Silver Medal at many shows for "best bloom" and the Gold Medal at the Botanical Gardens, 1914.

Baby Rambler or Madame Norbert Levavasseur (Levavasseur, 1903). The Crimson Rambler in dwarf form, with the same clear, brilliant, ruby-red color. Hardy and healthy everywhere, attaining a height of twenty inches, and blooming in profuse clusters until frost, and throughout the Winter if taken indoors.

Baby 'Tausendschoen or Louise Welter (Welter 1909). Small cupped blooms of veined rose with feathered edges of soft clear pink. A lovely little novelty, each bush forming a symmetrical bouquet.

Black Prince ( $W$. Paul, 1862). Deep, darl crimson, richly shaded, vigorous, richly perfumed. An old favorite.

Dorothy Page Roberts. H. T. Coppery pink suffused with apricot-yellow. Long pointed buds on long stems. Good foliage.

Duchess of Albany (See Red La France).

Duchess of Wellington (Alex. Dickson, 1909). Intense saffron-yellow, stained with deep crimson, deepening with the development of the flower to a coppery yellow of a distinct new shade. An admirable new Rose.

Fdward Mawley (S. McGredy, 1911). Velvety crimson of a deep, rich color on huge petals beautifully arranged to form faultless blooms of wonderful depth, sweetly perfumed and never off color in the hottest weather. Growth handsome, uniform and perfect, holding each bloom rigidly upright. An ideal, free and perpetual-flowering garden Rose. Awarded Gold Medal National Pose Society.
Etoile de France (Pernet-Ducher, 1904). A brilliant shade of clear red crimson velvet, centering to vivid cerise; large flowers on long, stiff stems: remarkably free blooming, and hardy. A very desirable bedding variety.

Florence Forrester (McGredy, 1914). Clear snow-white with lemon tinge; as the flowers age they become pure white; blooms are even larger than Paul Neyron. For size and substance it has no equal among hybrid teas. It is very sweetly perfumed. Received gold medal, National Rose Soriety.

Frau Karl Druschki. White American Beau. t y or S n o w Queen (P. Lam bert, 1901 ) This giant white Rose is without a doubt the most popular variety of the day. Buds of immense size, egg-shaped, with heavy waxy petals opening into a mammoth snowy white bloom of great refinement. Hardy as an oak tree. Can be planted anywhere.

General Jacqueminot (Roussel, 1852). Large velvety flowers of the most intense maroon-scarlet, each set in a cluster of rich green leaves. Blooms repeatedly through the Summer and Fall and is one of the most popular Roses grown.

cheral MacArthur (Hill, 1905). free blooming, every shoot producing a beautiful and richly colored bud and flower, which does not fade in the hottest sun. The flowers are large, double, of fine form, and very fragrant. One of the best garden Roses, no collection complete without it.

George Ahrends. (See Pink Frau Karl Druschki)

Golden Emblem (McGredy, 1917). It is so perpetual-flowering that as a garden and bedding Rose it has no rival. At its best it surpasses Marechal Niel in shape and formation, and with its wonderful coloring is a most wonderful Rose. The coloring is a yellow cadmium toning to sunflower yellow. The most striking and remarkable variety among modern Roses. Awarded the Gold Medal of the National Rose Society of England, also the American Rose Society's medal at Philadelphia. April, 1917, for the best Rose not yet in commerce.

Golden Ophelia. H. T. Rich golden flowers in greatest profusion on stout stems with glossy, dark green foliage. Especially adapted for cutting. A seedling of the popular Ophelia.

Gorgeous (McGredy, 1915). Strong, vigorous, free-branching growth; handsome dark olivegreen foliage. Flowers very large and full, exquisitely formed, produced freely and continuously on stout, erect stems. Color deep orange-yellow, heavily veined with reddish copper. Fine bedding and exhibition Rose.

Greetings of Liberty or Virginia R. Coxe (Geschwindt, 1897). Hardy in all sections; grows freely to four or five feet; vivid dazzling, fiery crimson; fragrant; a mass of gorgeous blooms on long stems. Favorite. 


\section{ROSES-Continued.}

Hoosier Beauty. Fragrant as Richmond, has inore petals, a stiffer stem, texture like velvet Glowing crimson-scarlet color, with darker shadings. Bud good length, opens well. Clean grower, little inclination to spot or milden. Very popular everywhere.

Irish Elegans. H. T. Single, bronze-orangescarlet. A very fine single Rose.

Irish Fire Flame. H. T. Single; fiery orangered, the most brilliant color imaginable.

robel H. T Single; carmine-red, shaded orange-scarlet; large petals. One of the best single Roses.

Joukheer J. L. Mock. This grand Rose is the strongest growing in the hybrid tea class. The blooms, which are produced with the greatest freedom, are carried on stiff and erect stems, and are of the largest size, of perfect formation, and highly perfumed. Color, clear imperial-pink: a glorious flower. Awarded two gold medals, one silver medal, and five first prizes in Europe. The largest flowers of all hybrid tea Roses. A wonderful Rose.

Kaiserin Iuguste Viktoria (P. Lambert, 1890). This beautiful Rose is celebrated the world over for its elegant, large pointed buds and full, fragrant flowers. The color is a delicate creamy white, with a faint tinge of lemon in the center.

IK. of IK. (Kitchener of Khartoum). A new Rose of great beauty; color of brilliant scarlet and does not easily fade. Free blooming and of excellent habit.

Iady Battersea. Red Kaiserin or Red Niphetos (Paul, 1901). The color, brilliant cherrycrimson, is most beautiful and striking; buds lons and pointed, flowers well formed; free blooming and vigorous growth. A very desirable garden variety.

Lady Hillingdon (Lowe \& Shawyer, 1910). Deep apricot-yellow, long pointed buds, a fine forcing and garden Rose; excellent for cutting. Is considered one of the best decorative Roses in its class. Awarded Gold Medal, National Rose Society.

La France (Guillot 1867). Pink, tinted silvery blush. Flowers large and borne freely. Delightfully fragrant, excelling nearly all others in this respect. One of the great favorites.

Laurent Carle. Color brilliant velvety crimson. Promising variety. Will pay to try it.

Louice Velter (See Baby Tausendschoen).

Los Ingeles (Howard and B. Smith, 1917). Originator's description: "Los Angeles is, by all odds, one of the finest Roses ever introduced. The growth is very vigorous, and produces a continuous succession of longstemmed flowers of a luminous flame-pink toned with coral and shaded with translucent gold at the base of the petals. In richness of fragrance it ecuals in intensity the finest Marechal Niel. The buds are lons and pointed and expand into a flower of mammoth proportions, while the beauty of form and ever increasing wealth of color is maintained from the incipient bud until the last petal drops.'

Madame Abel Chatener (Pernet-Ducher, 1895). A Rose of extraordinary merit. A free bloomer, with flowers of good size and substance. Color beautiful rosy carmine, with darkel shadings. Very richly colored. One of the finest varieties; should find a place in every Rose garden

Madame Caroline Testout (Pernet-Ducher, 1890). A grand Rose of the La France type. but with flowers larger and finer. Color bright satiny pink: very fragrant and free in bloom. One of the handsomest Roses and should be planted extensively.

Madame Norbert Levavasseur (See Baby Rambler)

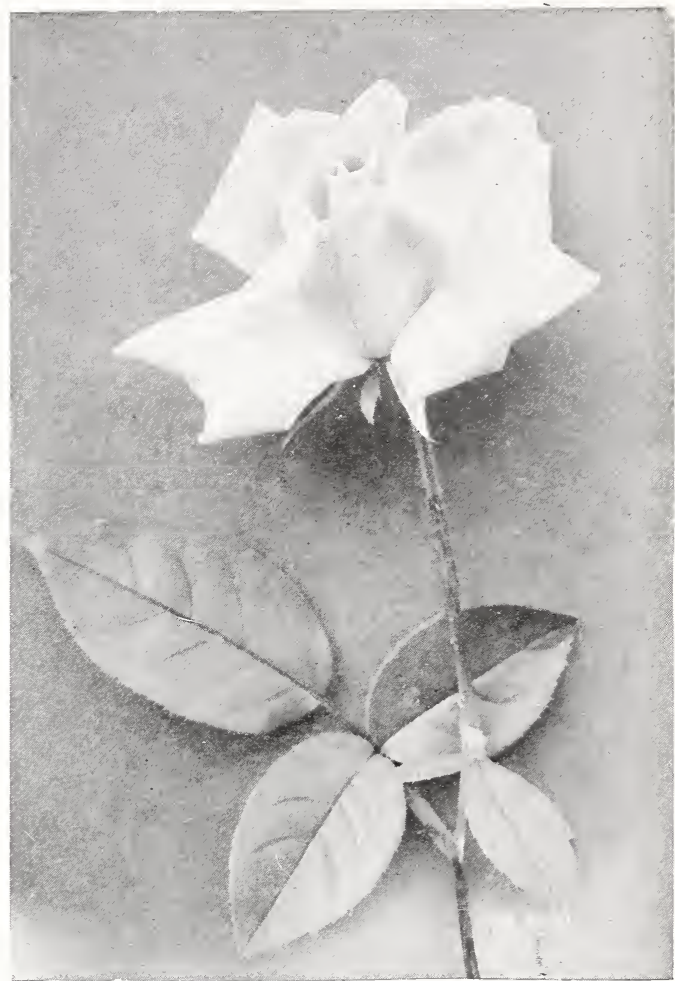

Kaiserin Auguste Viktoria.

Mabel Morse. H. T. Clear bright vellow, without shading. Color is particularly fine. Fragrant, vigorous and profuse. Gold Medal National Rose Society.

Maman Cochet (Cochet, 1892). Rich, rosy pink, shaded silvery rose on outer petals; exquisite in color and graceful in form from bud to bloom and delightfully fragrant; beautiful, healthy foliage and long stiff stems. Unquestionably the queen of pink Tea Roses and a leading cut flower variety.

Marshall P. Wilder (Ellwanger, 1884). Color bright cherry-carmine; fragrant, of vigorous growth, with fine foliage. One of the freest of the Hybrid Perpetuals to bloom. Undoubtedly a grand Rose.

Mignon (See Mlle. Cecile Brunner).

Mle. Cecile Brumer. Mignon or Sweetheart (Ducher, 1880). SaImon-pink. The clustered flowers are small, daintily formed and exquisitely colored. The little buds are especially beautiful. Blooms constantly. A truly charming Rose

Mrs. Indrew Carnegie (Cocker, 1913). This handsome new Rose receives the admiration of all for its beautiful shape and delightful fragrance. Pale lemon-yellow at base of petals, shading to pure white. Gold Nedal National Rose Society.

Mrs. Irthur R. Waddell (Pernet-Ducher, 1908). Long and pointed buds of rosy scarlet, opening coppery salmon; large semi-double and extremely showy. IIighly colored and free blooming. Foliage dark, glossy green. Extremely popular.

Mr's. Redford (1925). A new Rose with distinguished merits. Brilliant apricot orange of great beauty; long, pointed buds with fine, mildew-proof, leathery foliage. Free blooming. 


\section{ROSES-Continued.}

Mrs. George Shawyer (Lowe \& Shawyer, 1911). Brilliant rose-pink or bright peach-pink. Flower's large, well formed, with petals of good substance. Very free growth, with leathery foliage, every shoot tipped with a bud. Do not leave this Rose out of your collection.

Mrs. John Laing (Bennett, 1887). A beauty in clear, bright shining pink; each bud in its long, serrated calyx with adjacent foliage, forms a dainty and lovely boutonniere; immense, full blooms on long, stiff stems.

National Emblem (McGredy, 1915). Color is of a beautiful dark crimson, overlaid velvety crimson and shading to vermilion toward the edges. The buds are very long and pointed and of ivory-white substance. The flowers are quite full, every one coming perfect and are produced with marvelous freedom.

Ophelia (W. Paul, 1912). Brilliant salmonflesh shaded with rose on outer edges of petals, with a heart of glowing peach-pink and orange-yellow shadings, all passing finally to lighter shades; fragrant as Richmond, faultless form in bud and flower; erect habit, stiff, long stems; handsome, bright foliage; immune to mildew and black spot.

Orleans (Levavasseur, 1914). This is the showiest and prettiest of all the Baby Ramblers. When in bloom this Rose presents the appearance of a huge bouquet of deep cerise or geranium-pink with distinct showy center of pure white; the color is irresistible. The plant is a very rapid grower and flowers outlast almost any other Rose in existence. Awarded Gold Medal.

Perle d'Or (Guillot, 1883). Although not new this little Rose is very novel and beautiful with nankeen-yellow and orange centers. It is similar to Mlle. Cecile Brunner but is unsurpassed by that very popular Rose.

Perle von Godesbur' or Yellow Kaiserin (Schneider, 1902). Canary-yellow of a rich shade, passing toward white. A sport from and otherwise identical with the white.

Pink Frau Karł Druschki or George Arends (Hinner, 1910). The flowers are of large and massive proportions, surmounting stout canes in a most imposing manner. The color is a delightful flesh and bright shade of pink with silvery suffusions. Perfectly hardy in any locality.

Prince Camille de Rohan (E. Verdier, 1861). Universally known as "The Black Rose," owing to its very deep, velvety crimson color, passing to intense maroon, and shaded black; large handsome and fragrant blooms.

Queen Ilexandra. Intense vermilion color deeply shaded old gold on reverse of petals. Entirely unique, and may best be described as an advancement on the Juliet, richer and more strikingly colored, and with foliage shining and hardy, and entirely free from mildew and rust.

Red Kaiserin Auguste Viktoria. (See Lady Battersea).

Radiance (Cook, 1909). A brilliant rosy carmine, displaying beautiful rich and opaline tints in the open flower.

Red Ia France ( $W$. Paul, 1888). Two shades darker than its parent, the Pink La France, of which it is a duplicate in size, form and habit.

Red Niphetos (See Lady Battersea).

Rhea Reid (Hill, 1908). The flowers are of fine size and build, double to the center. Color a rich shade of cerise-crimson. Very free in growth and bloom. Won first honors at Paris in competition with all the choicest new Roses of Europe.

Richmond (Hill, 1905). Scarlet-crimson of a most brilliant hue; long pointed buds and beautifully striking flowers on tall, erect stems; handsome foliage; a rapid grower and a constant producer.

Rose Marie. A grand Rose of highest merit. A rich red that has come to stay. Might be described as a waternielon-red. Very desirable.

Snow Queen (See Frau Karl Druschki).

Sunburst (Pernet-Ducher, 1912). Orangecopper or golden orange and golden yellow, all intense shades, giving an extremely brilliant effect. A giant Rose, long stems, long pointed buds, vigorous, free and healthy, with splendid keeping uualities as a forcer; also an excellent bedder. Be sure to add this to your collection.

Swcetheart (See Mlle. Cecile Brunner).

Ulrich Brumner (Levet, 1881). This is really a magnificent Rose; extra large, bold flowers, full and globular; petals large and of good substance; color rich glowing crimson, elegantly flamed with scarlet; a good grower and fine bloomer.

Virginia R. Coxe (See Greetings of Liberty).

White American Beauty (See Frau Karl Druschki).

White La France or Angustine Guinoisseau (Guinoisseau, 1889). This magnificent Pose is pure white, having just a breath of rose tint blush, decidedly clouding the depth of its broad petals; the buds and flowers are extra large and very full and finely formed.

White Maman Cochet (Cook, 1897). Very large and beautifully formed in bud and bloom; pure white with faint pink flush on edges of petals. Vigorous and produces abundantly for cutting.

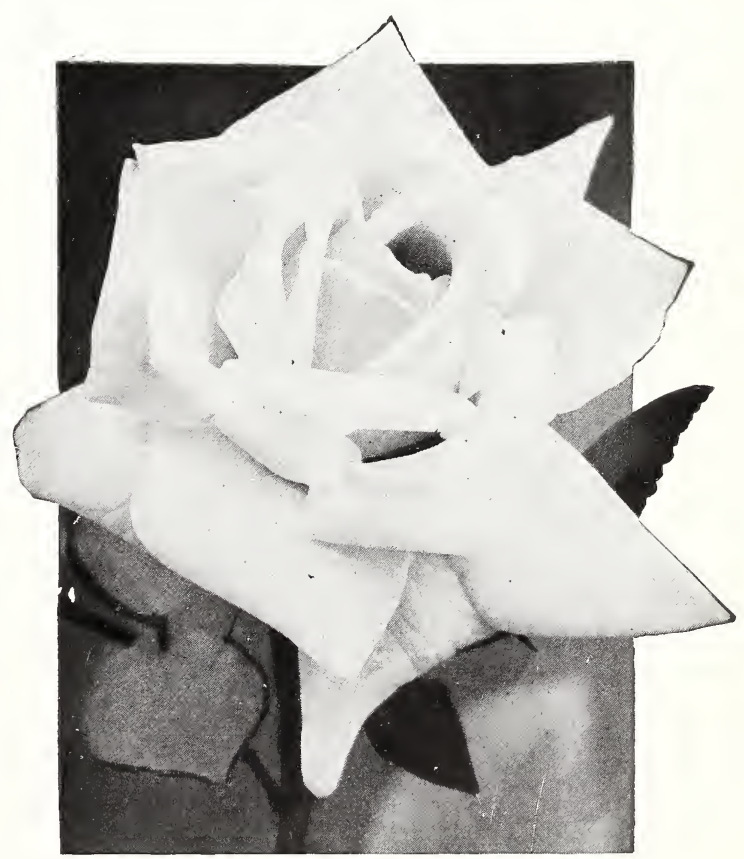

Ophelia. 


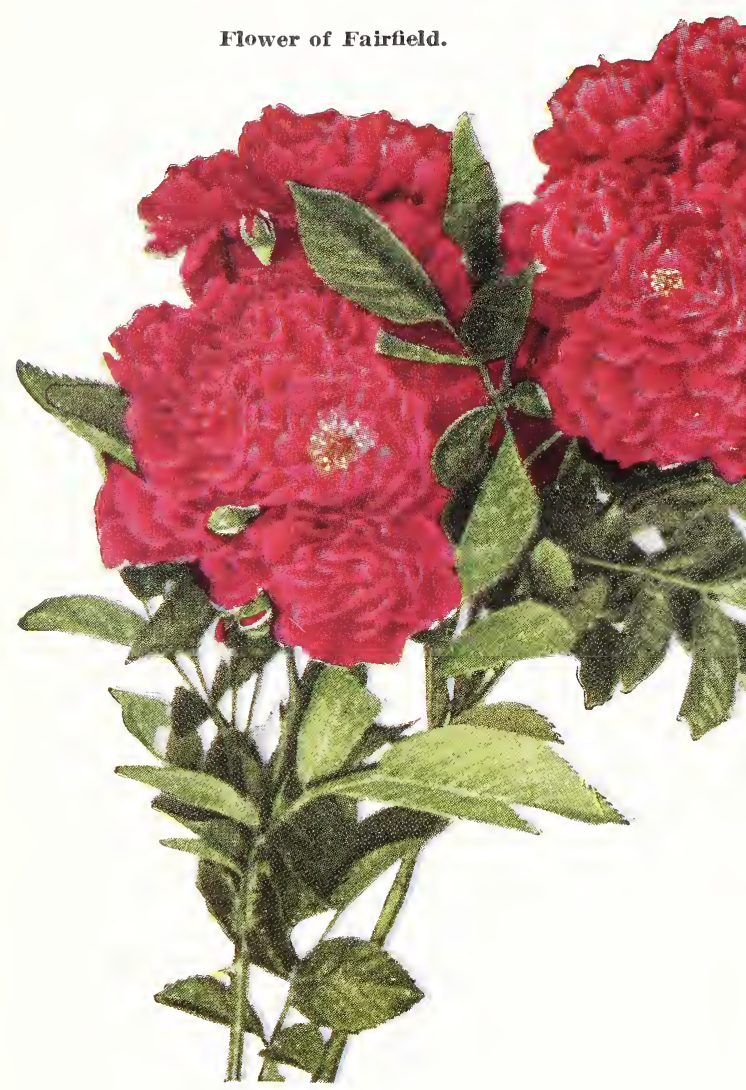

Wm. F. Dreer. This of the same parentage as the Los Angeles and is similar in shape and like that variety is beautiful in all stages of development. Silvery shell-pink suffused with golden yellow.

willowmere (Pernet-Ducher, 1913). Coral, rich shrimp-pink, shaded yellow in the center, and toning to carmine-pink toward the edges of the petals. Vigorous growth, erect and branching habit. Long carmined coral bud, carried on long stems. Very large flower, full and of elongated cup shape.

Yellow Kaiserin Auguste Viktoria. (See Perle von Godesburg).

\section{Hardy Climbing and Pillar Roses}

Strong, robust growers, bearing large clusters of fragrant flowers. Their rambling habit of growth makes them useful for covering arbors, porches, etc. Perfectly hardy.

Aglaia. (See Yellow Rambler).

American Pillar (Conard, 1909). A singleflowering variety of great beauty. The flowers are of enormous size, sometimes three to four inches across, of a lovely shade of apple blossom pink, with a clear white eye and cluster of yellow stamens. It forms a beautiful decorative subject throughout August.

Climbing Baby Rambler or Miss G. Messman (Messman, 1911). A true everblooming Crimson Rambler, a climbing sport from the original Crimson Baby Rambler. The combination of color and habit make this a desirable Rose.

Crimson Rambler (Turner, 1893). The most popular climber of today; a rapid producer of long heavy canes, reaching a height of ten to twenty feet in one season; rich clusters of bloom form a mass of vivid crimson beauty until late in the season. Hardy.
Dorothy Perkins (Perkins, 1902). Beautiful shell-pink color, which holds for a long time, fading finally to a lovely deep rose; very sweet scented; fully equal to Crimson Rambler in foliage, hardiness, habit of growth and blooming qualities.

Euphrosyme. (See Pink Rambler).

Excelsa. (See Red Dorothy Perkins).

Flower of Fairfield (Loudorf, 1908). A counterpart of Crimson Rambler in every respect, except it shows everblooming tendencies, many new growths being terminated with a cluster of flowers. It is frequently called the Everblooming Crimson Rambler.

Miss G. Messman. (See Climbing Baby Rambler).

Red Dorothy Perkins (Walsh, 1909). Intense crimson-scarlet; double flowers in brilliant clusters set in glossy, shining foliage which never mildews nor spots. Extremely vigorous and the handsomest of all red Roses.

Shower of Gold (Paul 1910). Deep golden yellow and orange flowers borne in splendid trusses forming a mass of bloom. Extremely long laterals and densely clad with a beautiful foliage, the leaves on upper side a vivid, glossy green, the under side and stems a reddish brown.

Tausendschoen or Thousand Beauties (Schwartz, 1906). Varying shades from a delicately flushed white to a deep pink or rosy carmine, in bright clusters of blossoms almost covering the handsome green foliage. A vigorous hardy climber with few thorns.

Thalia (See White Rambler).

White Rambler (Lambert, 1896). In habit of growth, foliage manner of blooming and shape of flowers, this is identical with Crimson Rambler, differing only in color, which is pure, clear white.

Yellow Rambler or Aglaia (Schmidt, 1895). Rapid grower; color a clear, decided yellow, changing to a beautiful cream. Blooms in clusters same as Crimson Rambler. Hardy.

\section{Hardy Perennials}

Under this head is included those hardy plants, the foliage of which dies to the ground each Winter. Every Spring a new and stronger growth may be expected. These plants are adapted to most soils, responding readily to thorough cultivation and occasional enrichings. The old tops should be cut down after the foliage has matured. We offer a few of the more common and hardy kinds.

\section{Hardy Perennial Phlox}

This is one of the most easily grown, hardy perennials. Their noble flowers are most beautiful during the Summer and Autumn months. Beauty. Delicate silver pink.

Gen. Von Heutsze. Salmon-pink, red eye. Independence. Pure white; good.

Niobe. A rich, velvety purple.

Pantheon. Bright pink, with faint halo.

R. P. Struthers. Cherry-red, deep red eye. 


\section{Best Hardy Phlox}

This list is made up of newer varieties and some that are very rare. Extra strong plants that will bloom the first season.

Baron von Dedem. Brilliant scarlet-red.

Bridesmaid. White with crimson center.

Elizabeth Campbell. Light salmon with dark center.

Embrazement. Brilliant orange.

Henri Murger. White, deep rose center.

Mme. Bezanson. Best crimson.

Obergartner Wittig. Bright magenta, carmine eye.

Rijnstroom. Pink, like Paul Neyron rose.

Sir Edwin Landseer. Crimson-scarlet with red center.

Widar. Light reddish violet, white center.

GOLDEN GLOW (Rudbeckia laciniata). Strong robust grower, attaining height of five or six feet, producing masses of double, golden yellow, dahlia-like flowers from July to September. Hardy everywhere.

DAY LILY (Hemerocallis). One of the hardiest and easiest grown of the herbaceous perennials. Narrow, grasslike foliage, yellow flowers in early summer. Roots fleshy tubers and should be divided occasionally.

\section{Iris}

The Irises are very popular and easily grown, ranging through yellow, blue, purple, white and mahogany colors. A dry sunny location with a moderately rich soil suits them best. Perfectly hardy. There is nothing prettier than this Liberty Iris, blooming in the late Spring and early Summer months. The large plants we send our customers will bloom the first season planted. In the descriptions, "S" means the standards, and " $F$ "' the falls.

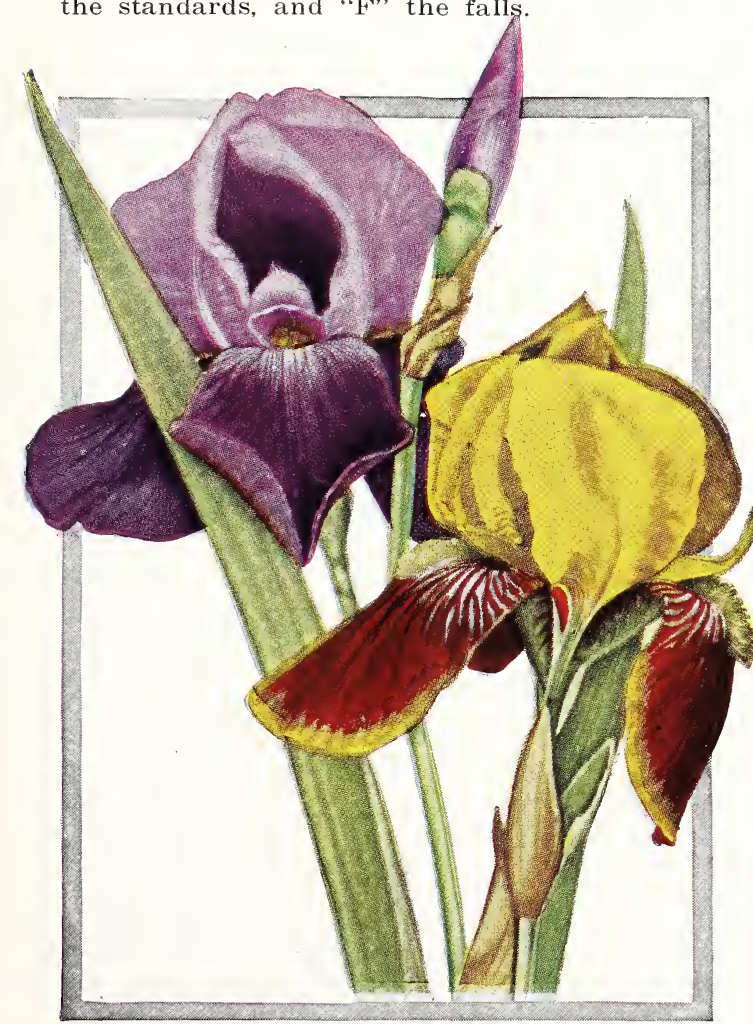

Iris, Pallida Dalmatica and Honorabile.

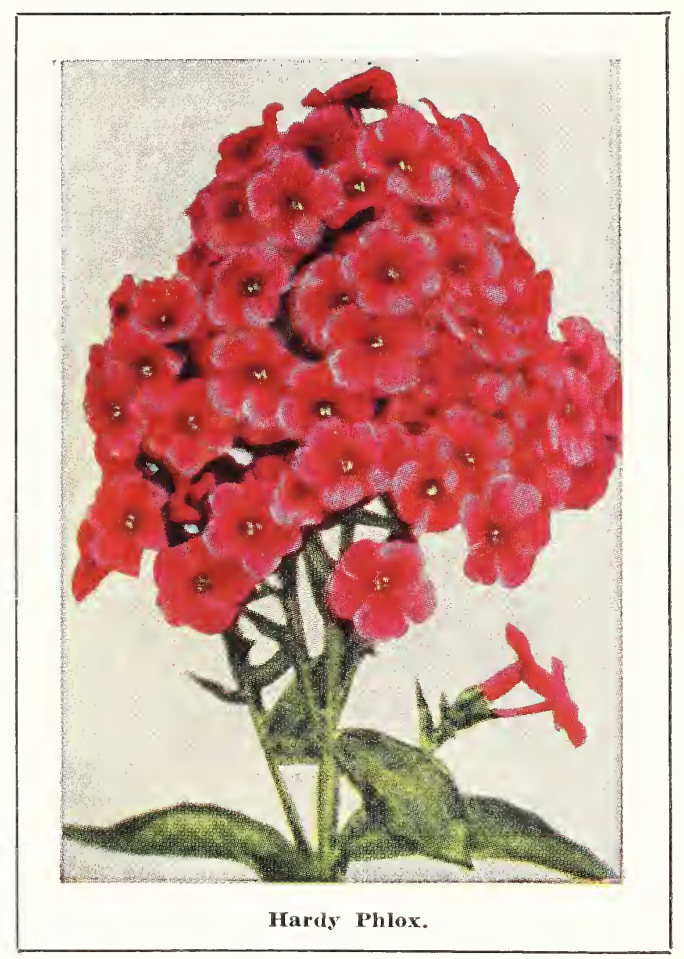

Ambassadeur. S. dull purplish bronze; F. deep velvety maroon. Beards and styles yellow.

Ballerine. S. light violet-blue, broadly waved at margin. F. large, a deeper snade than the standards. Very sweet scented.

Catalosa. Rose and violet; one of the few new and scarce varieties of special merit.

Lohengrin. Uniform lilac-rose.

Florentina. Creamy white, faintly flushed lavender.

Her Majesty. S. rose-pink; F. bright crimson, shaded darker.

Honorabile. Golden yellow; F. mahoganybrown.

Isoline. S. silvery rose flushed bronze; F. mauve with gold tint.

Lent A. Williamson. Early. S. very broad, soft campanula-violet; $F$. very large velvety royal purple. Brilliant gold beard.

Madame Chereau. White, with border of clear blue.

Opera. Early. S. bright reddish lilac; F. deep velvety purple-lilac. Beard yellow.

Pallida Dalmatica. Delicate lavender; F. deep lavender.

Prosper Laugier. Deepest velvety crimson, richly veined at throat.

Purple I'rince. Violet-blue; F. dark purple.

Queen Caterina. A large iridescent pale lavender-violet with yellow beard. Large and vigorous.

Queen of May. Rose-lilac.

Roseway. Early. S. and F. deep red-pink with a blood-orange beard. Strong, branching stems.

Seminole. S. dark violet-rose; F. rich velvety crimson; brilliant orange beard. 


\section{Hardy Ornamental Climbing Vines}

\section{Ampelopsis}

Imerican Iry or Virginia Creeper (Quinquefolia). A native vine of hardy, rapid growth, with large, luxuriant foliage, which in $\mathrm{Au}$ tumn takes on the most gorgeous coloring. One of the finest vines for covering walls, verandas, etc.

English Iry. Leaves a dark, shiny green. Used in England for covering old trees. A close growing variety.

Boston or Japanese Iry (Veitchi). Leaves a little smaller and more ivylike in form than the foregoing. The plant requires some protection until it is established.

\section{Clematis}

Clematis plants of the improved sorts are exceedingly hardy and produce beautiful large flowers in great abundance during a long period. They do best in a rich soil, in a sunny situation. The young shoots that spring up after transplanting sometimes die down, but if the root is left in the ground undisturbed, it will most always send forth strong shoots early the following Spring, which will bear handsome blossoms the same season.

Henryi. Fine bloomer; flowers large, of a bright, beautiful creamy white, consisting generally of from six to eight sepals; it is not only a vigorous grower but a remarkably free and continuous bloomer.

Jackmani. The flowers, when fully expanded, are from four to six inches in diameter; intense violet-purple, with a rich velvety appearance, distinctly veined; flowers continually from July to October.

Madame Fdonard Andre. This is the nearest approach to a bright red Clematis and has been called the Crimson Jackmani. The plant is a strong, vigorous grower, and very free in bloom.

Paniculata (New, Sweet Scented Japan Clematis). No introduction of recent years has met with such ready sale and given such satisfaction wherever planted. It grows and thrives anywhere and is a very rapid grower and profuse bloomer. Flowers are pure white, borne in large clusters, converting the

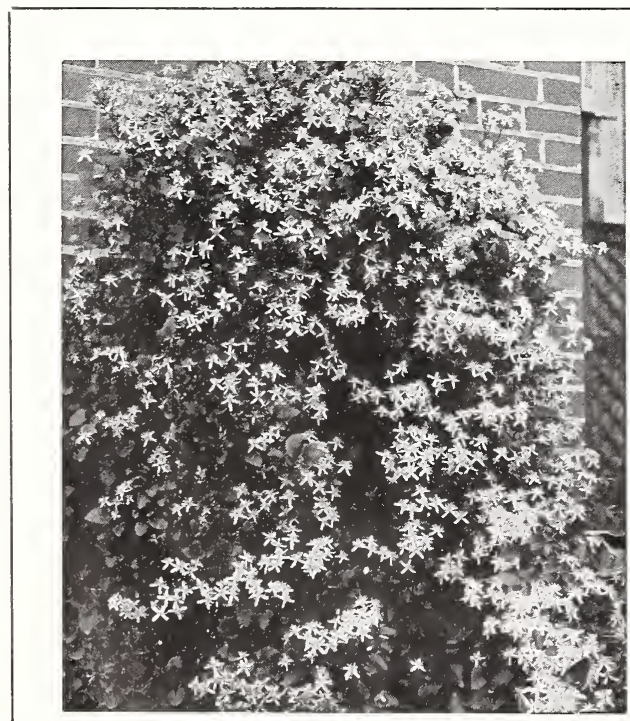

Clematis Panieulata.

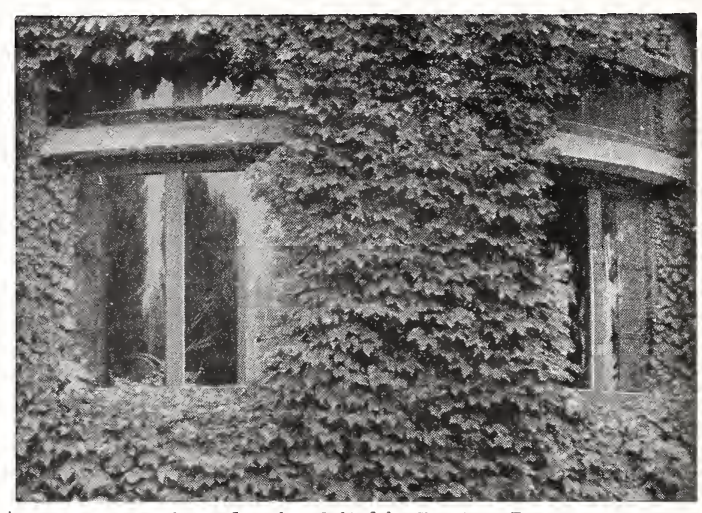

Ampelopsis Veitchi-Boston Iry.

plant into a perfect mass of white. Its extreme hardiness, bright green foliage and delightfully fragrant flowers serve to make this one of the finest hardy climbing plants in cultivation.

\section{Honeysuckle - Lonicera}

Belgica (Monthly Fragrant or Dutch Honeysuckle). Blooms all Summer; red and yellow flowers; very fragrant.

Halliana. A new, hardy variety from Japan, and has proved to be one of the best Honeysuckles grown. Blooms from June to November. It is almost evergreen and one of the most fragrant. White, changing to yellow.

Red Coral (Sempervirens). A hardy, rapid grower; flowers are red and fragrant.

\section{Trumpet Flower - Tecoma}

Radicans. A hardy, rapid growing climber, with large, scarlet, trumpet-shaped flowers Blooms almost continuously throughout the Summer season.

\section{Wisteria}

Chinese Purple (Sinensis). Most beautiful climber; of rapid growth, producing fine large clusters of lovely blue in great masses. It is very hardy, and one of the most superb vines ever introduced.

Chinese White (Sinensis alba). Flowers borne in long, drooping clusters as in the purple variety; pure white in color, making a striking and elegant contrast.

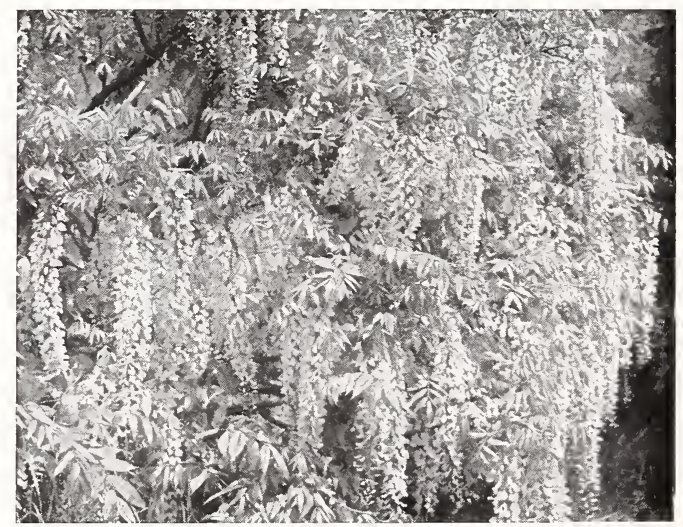

Chinese Wisteria. 


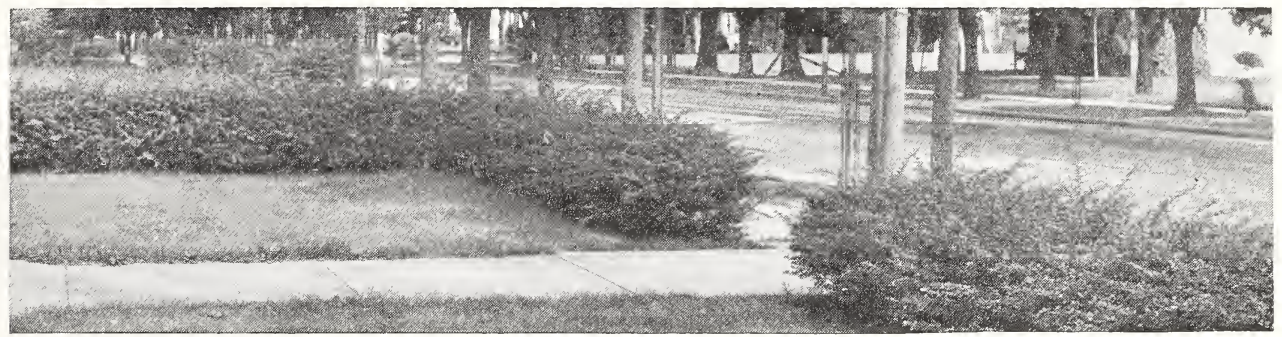

Barberry Hedge.

\section{Ornamental Hedges}

Nothing could be more beautiful than a neatly trimmed hedge, and they are useful for boundary fences, screens, etc. We give below some of the best varieties for ornamental hedges, screens, wind breaks or boundaries.

In starting a hedge, to secure the best results, the plants should be set in two rows, a foot between the rows, and plants set alternate, a foot apart in the row, which will make a plant every six inches in length of the hedge. Thus a hundred feet will require two hundred plants.

Good results may be obtained by planting in single rows but more time will be required to get a thick hedge.

Pruning should commence as soon as limbs get large enough to form required size of hedge. Frequent pruning will cause hedge to thicken up and become compact.

$x$

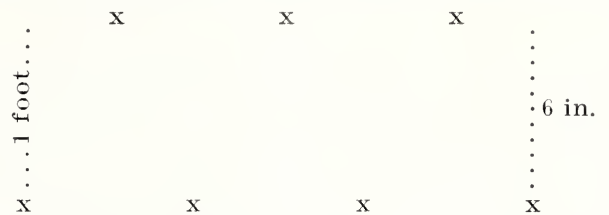

Privet, English. Hardy. These grand shrubs are extensively used for hedges and screens and occasionally given space in the shrub plantations for the beauty of their flowers and berries. They are hardy and vigorous, thriving in almost any fertile soil and stand clipping admirably.

American Arbor-Vitae (See page 17).

Barberry Thunbergi. Very neat and dense in growth; graceful, drooping branches. Yellow flowers, followed by scarlet fruit, borne in dense profusion on long stems, and

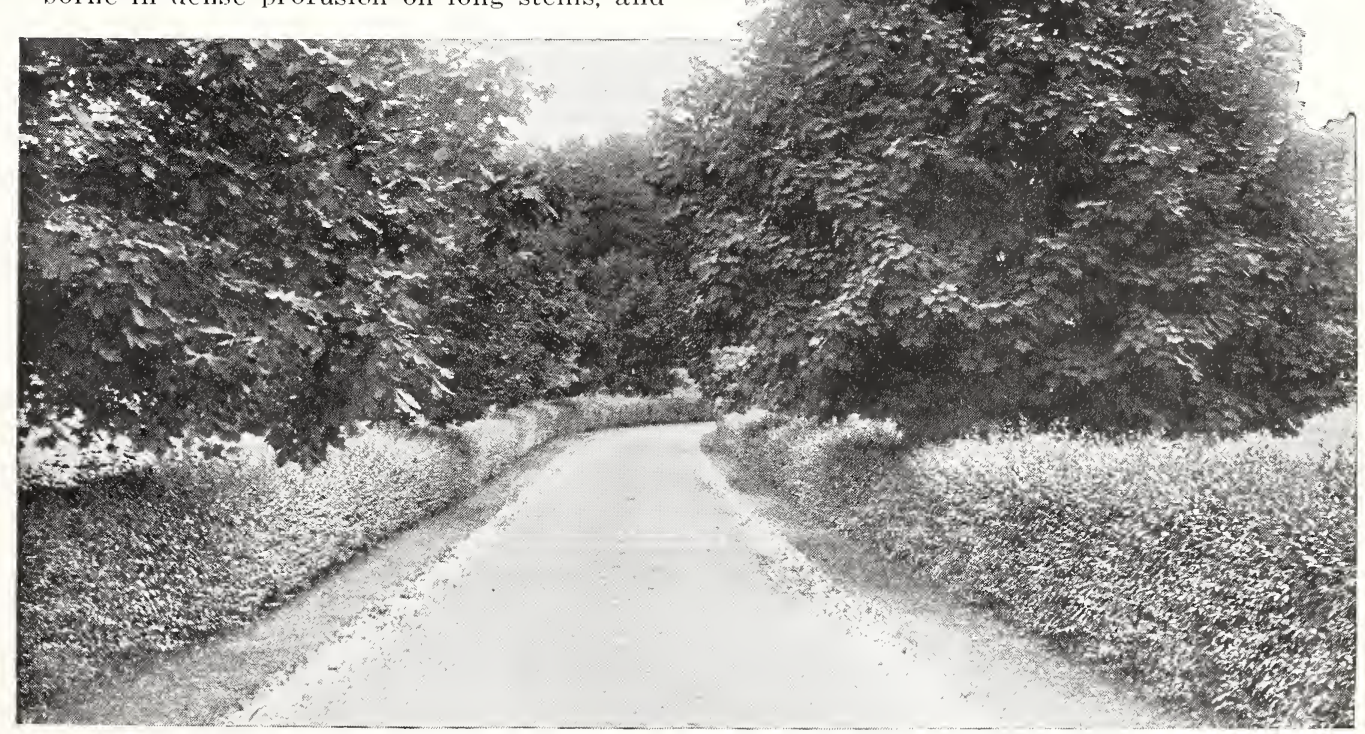

Privet Hedge.

clinging through most of the Winter; leaves turn to scarlet and gold in Autumn. Very choice for hedging. 


\section{Peonies}

The wonderful improvement made during recent years in these old-fashioned hardy plants has brought them into renewed popularity. The gorgeous flowers which rival the finest Roses in size, form and color are produced in great abundance. After once being planted they require little care and attention, thrive anywhere and are absolutely hardy even in the coldest climates; each year after planting they grow into greater value, producing more and more flowers. They are not troubled with insect pests. Try some of our Peonies and see what grand flowers they are.

Time to Plant. The best time to plant the roots is in the Fall when the plants have matured and are dormant. If planted in the Fall and given proper care, they will bloom the first year planted.

Size of Roots. The roots we offer are divisions having from three to five eyes. Those desiring heavier roots, please write for special prices.

Albatre (Crousse, 1885). Very large, very double, rose type. Irory-white, central petals margined with carmine. Fragrant. Strong, rigorous, tall grower, very free bloomer. Midseason. One of the grandest white Peonies.

Asa Gray (Crousse, 1886). Large, pale lilac bloom, sprinkled with lilac dots. Free bloomer. Fragrant. Very distinct and beautiful.

Boule de Neige (Calot, 1862). Very large, medium globular, compact, semi-rose type. Milk white, guards and center prominently flecked crimson. Tall, erect, free bloomer For cut bloom extra good. A choice early midseason variety.

Charlemagne (Crousse, 1880). Very compact, large, globular, lilac-white, rose type with a slight blush center. Odor pleasant. Late, free bloomer; good variety.

Claire Dubois (Crousse, 1886). Very large, globular, rose type. Uniform color, delicate satiny pink, tipped silvery white. Erect, tall, strong grower. Late. One of the finest pink Peonies we have.

Couronne d'Or (Calot, 1873). Large, flat, semi-rose type. Pure white, with a ring of yellow stamens around a tuft of center petals, tipped carmine. Solidly and perfectly built from edge to center. Fragrant. A good grower and reliable late bloomer. Keeps well when cut for bloom. One of the very choicest and best Peonies in cultivation.

Dorchester (Richardson, 1870). Large, compact, rose type. Hydrangea-pink. Odor pleasant. Medium dwarf. Upright, free bloomer. Late. Extra good.

Duke of Wellington (Calot, 1859). Very large, well formed, sulphur-white bloom. Habit ideal. Stems very firm and long. A strong grower and free bloomer. Very fragrant. Good late cut bloom. Very beautiful variety.

Duchesse de Nemours (Calot, 1856). Very fine cup-shaped bloom; guard petals pure white, sulphur-white center with greenish reflex. Very fine bud; fragrant. Good grower and free bloomer. An early white Peony of great beauty.

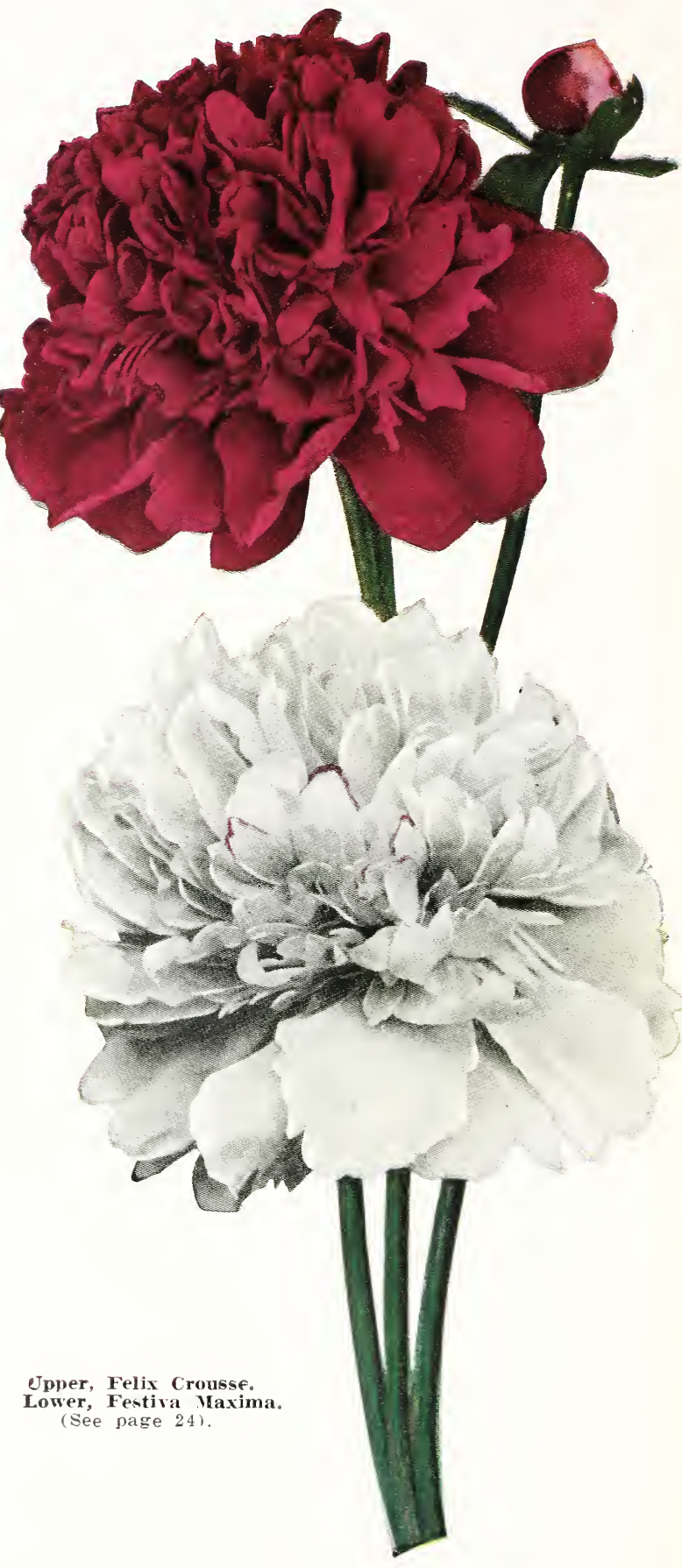

Duchesse d'Orleans (Guerin, 1846). Very pretty, deep pink, with violaceous tints on center petals interspersed with salmon. Fragrant. A good midseason cut flower variety.

Edulis Superba (Lemoine, 1824). Large, loose, flat crown type. A most beautiful bright clear mauve-pink with silvery reflex. Very fragrant. One of the very best commercial pinks for Decoration Day. 


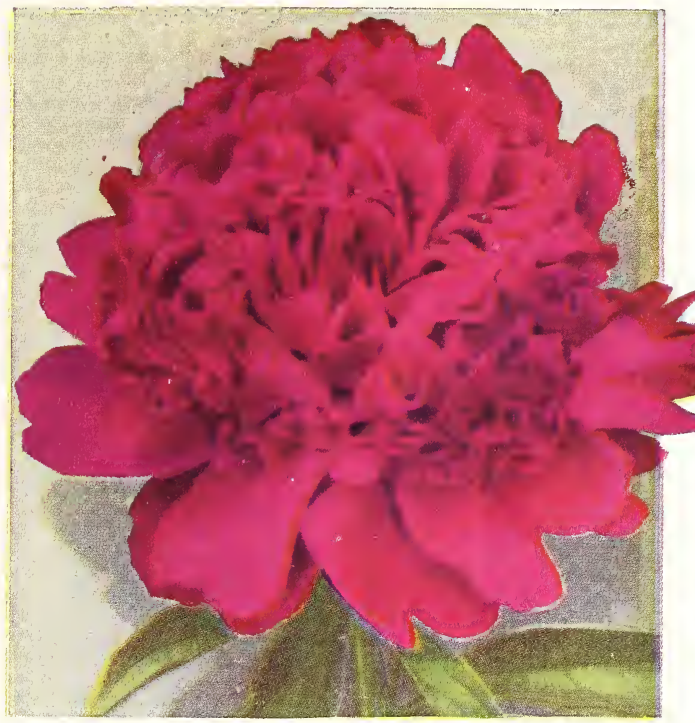

L'Eclatante

Eugene Verdier (Calot, 1864). Very large, compact, typical rose bloom. Color hydrangea-pink with outer guard petals lilacwhite. Odor pleasant. Extra strong, vigor ous growing plant, rather dwarf habit, extra strong stems, free bloomer. Good cut flower Peony. One of the best late varieties of perfect habit. Extra.

Felix Crousse (Crousse, 1881). Large, globular, typical bomb type. Brilliant red. Fragrant. Strong, vigorous grower, medium late. Good cut flower variety. Both color and size are startling. We place Felix Crousse in the front rank of all the red Peonies.

Festiva Maxima (Miellez, 1851). Enormous, globular, rose type bloom; often 7 to 9 inches in diameter, on strong, extra long stems. Pure white center prominently flecked bright crimson. Free, early bloomer and very fragrant. The most popular white variety for cut flowers.

General Bertrand (Guerin, 1845). Large, compact, globular, typical bomb. Uniform solferino-red, center slightly tipped silver. Tall, strong, upright grower. Very fragrant, early, handsome variety of bright color.

General Dodds (Crousse, 1893). Very large, globular, compact, semi-rose type. Uniform dark Tyrian rose, guards splashed green, a few white petals in center. Tall, strong grower, free bloomer. Late. Extra.

Golden Harvest (Rosenfield, 1900). Large size, loose, bomb or informal rose typie. Guards pale lilac-rose, center creamy white, developing many wide petals of a peachblossom pink. Odor pleasant. Dwarf habit, very free bloomer. Midseason. A most beautiful variety.

L'Eclatante (Calot, 1860). Bomb type, midseason. Flowers very double and full; colors deep brilliant, velvety crimson. Extra good cut flower variety.

Livingstone (Crousse, 1879). Rose type; late. Very full imbricated bloom; both buds and flowers are large and beautiful. Color pale lilac-rose with sheen of silver; very free, sure bloomer in clusters; upright, erect grower; fine cut flower variety. One of the prize winners.
L'Indispensable. A variety of unknown French origin. Very large full bloom of a delicate shell-pink. Tall, strong grower; midseason. A fine sort.

Madame Calot (Miellez, 1856). Large, pale hydrangea-pink; rose type, center shaded slightly darker with a sulphur tint in collar. Very fragrant. Medium tall, strong grower, free, sure bloomer. One of the desirable Peonies. Early.

Madame de Verneville (Crousse, 1885). Large, very full, bomb type. Broad guard petals pure white; center delicate rosy white tinted sulphur, fading to pure white, with carmine tipped central petals. Fragrant. Extra free bloomer. A very early white variety of great beauty.

Mademoiselle Leonie Calot (Calot, 1861). Very full, rose type bloom, perfect in form. Color a delicate rose-white with soft lilac-pink center, tinted with salmon. A tall grower and blooms so freely that its delicate colored blossoms hide the plant. Medium to late. A charming variety.

Marie Lemoine (Calot, 1869). Massive, very compact, rose type blooms with a rather flat center; white with cream-white center with an occasional carmine line on central petals. Fragrant; of strong, vigorous growth, medium height, with extra good stem; blooms freely and very late. A good landscape variety, good cut flower and grand in every way. Indispensable.

Marie Stuart (Calot, 1856). Crown type; midseason. Flesh-pink fading to white at base of petals. Tall grower, free bloomer, with a pleasing fragrance. Extra fine.

Monsieur Jules Elie (Crousse, 1888). Bomb type, early midseason. Immense, globular, very full flowers. Color an ideal glossy lilacpink, shading to deeper rose at the base, the entire bloom overlaid with a sheen of silver that fairly shimmers in the sunlight. Very fragrant. A good keeper, thus a good cut flower. An unapproachable variety from any standpoint.

Queen Victoria (Whitley). Bomb type; early midseason. The very best every-day white. For cut flowers a good keeper; a very free bloomer. Flowers of good substance and color, guard petals white with faint blush, creamy center. Fragrant. An old standby.

Rubra Triumphans (Delache, 1854). Type of bloom semi-double, globular, loose. Color dark, satiny crimson. The foliage is also very dark, with reddish stalks, presenting, especially in the early season, a pleasing contrast when planted with a light green foliage sort like Marie Lemoine. Early midseason. Fragrant.

Thryne. Light pink, center sulphur, changing to nearly white; strong grower and free bloomer. Midseason. Fragrant.

\section{Early May Flowering Peonies}

These varieties bloom from two to three weeks earlier than the Chinensis section. Always in bloom during the month of May. The Peonies of our mothers' gardens.

Officinalis Alba (Syn. Mutabilis). Pretty bud; large, full bloom; glossy, soft pink, shaded chamois, changing to pure white.

Officinalis Rosea. Full double bloom, soft rose. Some claim this to have the prettiest pink shade of all the Peonies.

Officinalis Rubra. Large globular bloom; brilliant crimson. This is the early-flowering red Peony so common to the old-time gardens, much used on Memorial Day, when the Chinese Peonies bloom too late. 


\section{Spraying Calendar}

This applies broadly to all parts of the Northwest.

There is no spraying that will cure everything. Tse the ones that fit your case. For information about insect pests, plant diseases and spraying, write to the Botanist or Entomologist of the Experiment Station,

\section{How to Spray}

Spray thoroughly. Direct your attention to the hardest places to reach. Cover every surface. Wet behind the buds. Reach the bottom of every crack. Fill the lower calyx cup. Do not try to economize on spray. For all crchard spraying use a high-pressure pump (at least 200 lbs.). ['se Bordeaux nozzles only. Use an 8 -foot spray rod. Have a crook to set the nozzle at an angle of forty-five degrees. Spray from a tower it the trees are beyond your reach.

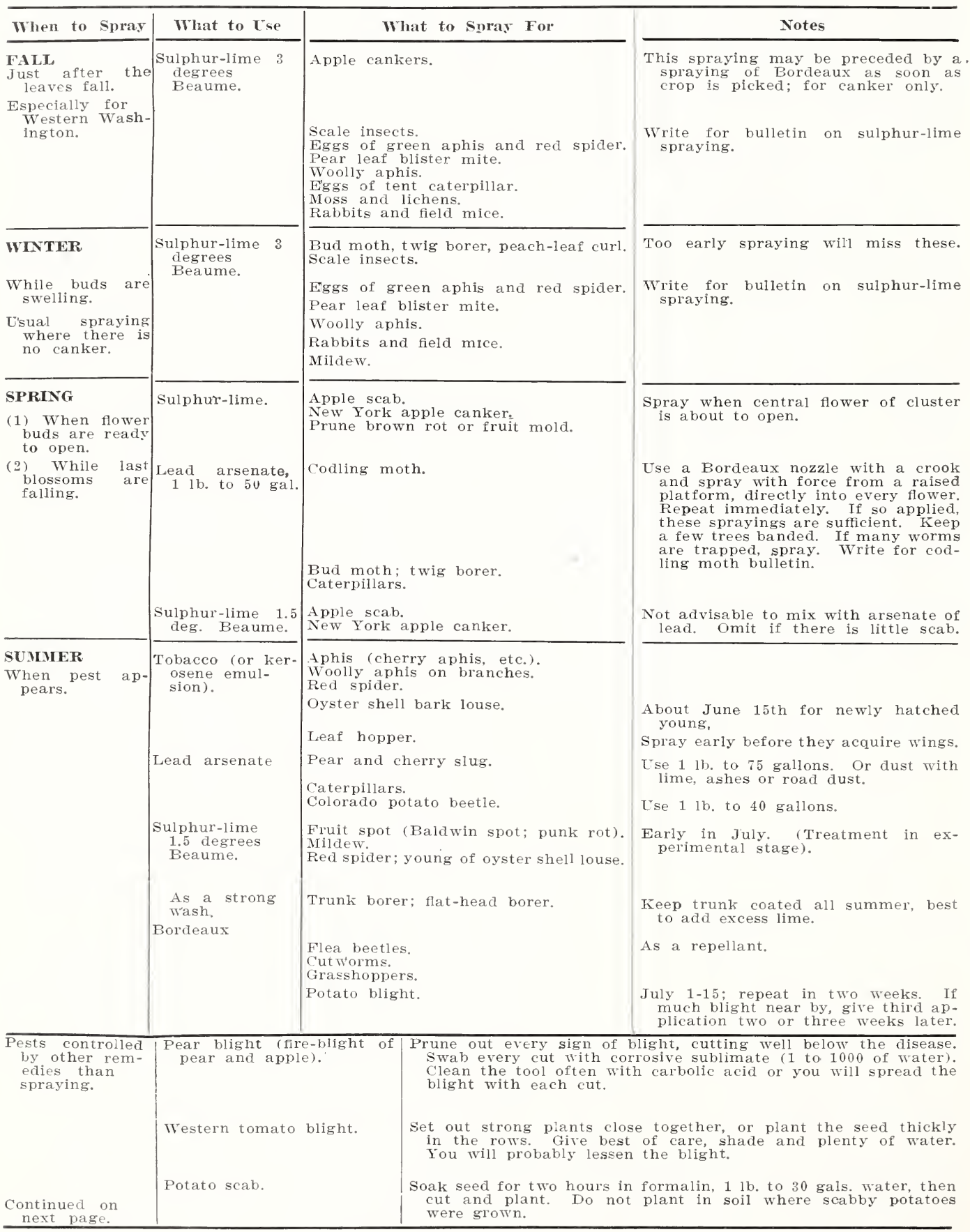




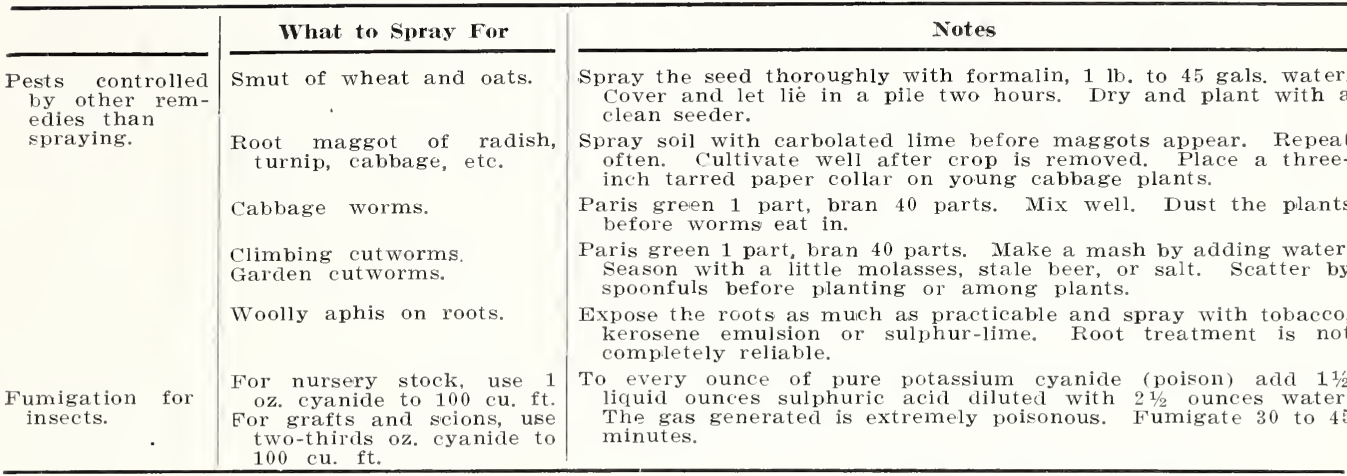

\section{Sulphur-Lime}

Sulphu 1 pound Fresh stone lime $1 / 2$ gallori Slake the lime in the cooker. Add the sulphur and the water. Boil briskly till the sulphur is dissolved (about 45 minutes), stirring continuously and keeping the cooker covered. As it boils down keep adding water. When finished let settle. Use only the clear liquid, which may be stored if kept from the air Prepared in this way sulphur-lime should have a hydrometer reading of about 26 de

For use, any concentrated sulphur-lime may be For use, any concentrated sulphur-lim
aluted according to the following table:

\begin{tabular}{|c|c|c|c|}
\hline \multicolumn{2}{|c|}{$\begin{array}{l}\text { Hydrometer Test of } \\
\text { Concentrate }\end{array}$} & \multicolumn{2}{|c|}{ To make Dilute Spray } \\
\hline $\begin{array}{l}\text { Beaume } \\
\text { degrees }\end{array}$ & $\begin{array}{l}\text { Specific } \\
\text { glavity }\end{array}$ & $\begin{array}{l}\text { Beaume, } 3^{\circ} \\
\text { Sp. gr. } 1.02 \\
1 \text { lb. sulphur } \\
\text { in } 5 \text { gals. }\end{array}$ & $\begin{array}{l}\text { Peaume, } 1.5^{\circ} \\
\text { Sp. gr. } 1.01 \\
1 \text { lb. sulphur } \\
\text { in } 10 \text { gals. }\end{array}$ \\
\hline $\begin{array}{l}34 \\
32 \\
30 \\
28 \\
26 \\
24 \\
20 \\
16\end{array}$ & $\begin{array}{l}1.302 \\
1.279 \\
1.259 \\
1.236 \\
1.215 \\
1.196 \\
1.158 \\
1.122\end{array}$ & $\begin{array}{r}-14 \text { water } \\
13 \\
12 \\
11 \\
10 \\
9 \\
7 \\
6\end{array}$ & $\begin{array}{r}1-28 \\
26 \\
24 \\
22 \\
20 \\
18 \\
14 \\
11\end{array}$ \\
\hline
\end{tabular}

\section{Carbolated Lime}

Lime 10 pounds Carbolic acid $\ldots \ldots \ldots \ldots \ldots \ldots \ldots \ldots \ldots \ldots \ldots \ldots \ldots \ldots \ldots \ldots$ pint or more Slake the lime with a little water, add the rest of the water and the carbolic acid.

\section{Arsenate of Lead}

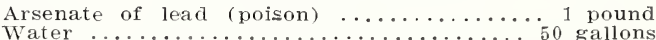

For newly hatched insects it is not necessary to use it stronger. Mix well first with a small amount of water. Powdered arsenate of lead is about twice as strong as the paste. Do not use arsenate that settles
quickly.

\section{Bordeaux}

Bluestone $\ldots \ldots \ldots$

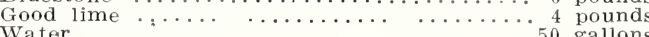
.... 50 gallons

Dissolve the bluestone by suspending it in a sack in 25 gallons of water in a barrel. Slake the lime in another vessel, adding a little water slowly, and dilute to 25 gallons. Mix the two thoroughly. Even the best Bordeaux may scorch in rainy weather.

For double strength Bordeaux use twice as much bluestone and lime.

\section{Kerosene Emulsion}

2 gallons Whale-oil soap ...................... $1 / 2$ pound Dissolve the soap in the water by boiling, and add the suds boiling hot to the kerosene, away from the fire. The mixture is then to be agitated violently, preferably by pumping it back on itself with a force pump. After four or five minutes the mixture suddenly becomes creamy in consistency. If well made, the cream will stand for a long time without free oil rising to the surface. Unless otherwise stated, use 1 gallon of the emulsion to 12 gallons of water in spraying: One quart soft-soap or 1 pound laundry soap may be used instead of the whale-oil soap.

\section{N D E X}

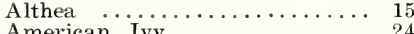

American Ivy $\ldots \ldots \ldots \ldots \ldots \ldots, 24$

Ampelopsis $\ldots \ldots \ldots \ldots \ldots \ldots \ldots \ldots{ }^{24}$

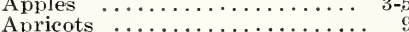

Arbor-Vitae ................... 17

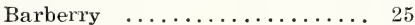

Birch $\ldots \ldots \ldots \ldots \ldots \ldots \ldots \ldots$ 13, 14

Blackberries $\ldots \ldots \ldots \ldots \ldots \ldots \ldots, 12$

Boston Ivy $\ldots \ldots \ldots \ldots \ldots \ldots \ldots 24$

Buddleia $\ldots \ldots \ldots \ldots \ldots \ldots \ldots \ldots \ldots$

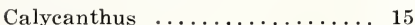

Catalpa ..................... 13

Cherries ............... 6

Clematis $\ldots \ldots \ldots \ldots \ldots \ldots \ldots 24$

Crab Apples ............ 5

Crab, Flowering .......... 13

Currants ................. 11

Cydonia ................ 17

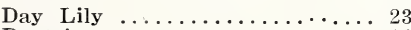

Deutzia ............... 16

Dewberry .............. 12

Elder ............... 16

English $\dddot{\text { Ivy }} \ldots \ldots \ldots \ldots \ldots \ldots \ldots \ldots \ldots .24$

Evergreens .............. 17

Forsythia ............. 16

Fruits .............. $2-12$

Golden Bell ........... 16

Golden Glow . . . . . . . . 23

Gooseberries $\ldots \ldots \ldots \ldots \ldots \ldots \ldots 12$

Grapes .................. 10

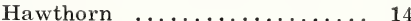

Hedget

Hibiscus

Gi.......

Honeysuckle, Climbing ...... 24

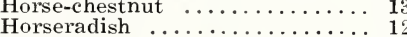

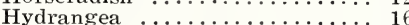

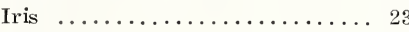

Juniper ................ 17

Kerria .............. 16

Lilac $\ldots \ldots \ldots \ldots \ldots \ldots \ldots \ldots \ldots \ldots$

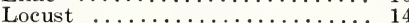

Lonicera $\ldots \ldots \ldots \ldots \ldots \ldots \ldots \ldots \ldots \ldots \ldots \ldots \ldots \ldots, 24$

Mahonia ............... 16

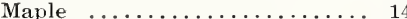

Mock Orange ............. 17

Mountain Ash $\ldots \ldots \ldots \ldots \ldots \ldots \ldots .1$

Mulberries $\ldots \ldots \ldots \ldots \ldots \ldots \ldots \ldots 12$

Nectarines $\ldots \ldots \ldots \ldots \ldots \ldots \ldots . \ldots \ldots \ldots \ldots \ldots$

Nuts $\ldots \ldots \ldots \ldots \ldots \ldots \ldots \ldots \ldots$,

Peaches.$\ldots \ldots \ldots \ldots \ldots \ldots \ldots \ldots 7$

Pears $\ldots \ldots \ldots \ldots \ldots \ldots \ldots \ldots, 5$

Peonies $\ldots \ldots \ldots \ldots \ldots \ldots \ldots 26,27$

Perennials $\ldots \ldots \ldots \ldots \ldots \ldots \ldots 22,23$

Phlox $\ldots \ldots \ldots \ldots \ldots \ldots \ldots \ldots \ldots \ldots \ldots \ldots, 23$

Picea....

Plane $\ldots \ldots \ldots \ldots \ldots \ldots \ldots \ldots 14$

Plums $\ldots \ldots \ldots \ldots \ldots \ldots \ldots \ldots . \ldots . \ldots . \ldots$
Plum, Flowering ......... 17

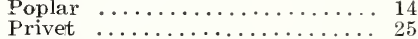

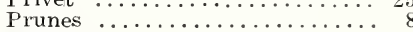

Prunus $\ldots \ldots \ldots \ldots \ldots \ldots \ldots \ldots 17$

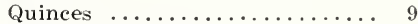

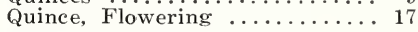

Raspberries ............. 11

Rhubarb ................ 12

Roses ............... 18-22

Sambucus $\ldots \ldots \ldots \ldots \ldots \ldots \ldots 16$

Shade Trees .......... 13, 14

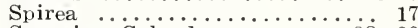

Spraying Calendar ......... 28,29

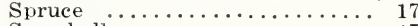

Snowball ............... 17

Snowberry $\ldots \ldots \ldots \ldots \ldots \ldots \ldots \ldots 17$

Sycamore $\ldots \ldots \ldots \ldots \ldots \ldots \ldots \ldots$
Symphoricarpos $\ldots \ldots \ldots \ldots \ldots$

Syringa ................. 16

Tecoma ................ 24

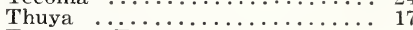

Trumpet Flower ............... 24

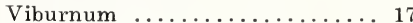

Vines .................. 24

Virginia Creeper ............ 24

Weeping Trees ............ 14

Weigela ................ 17

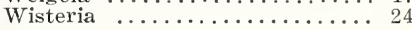

Yucca ............... 17 


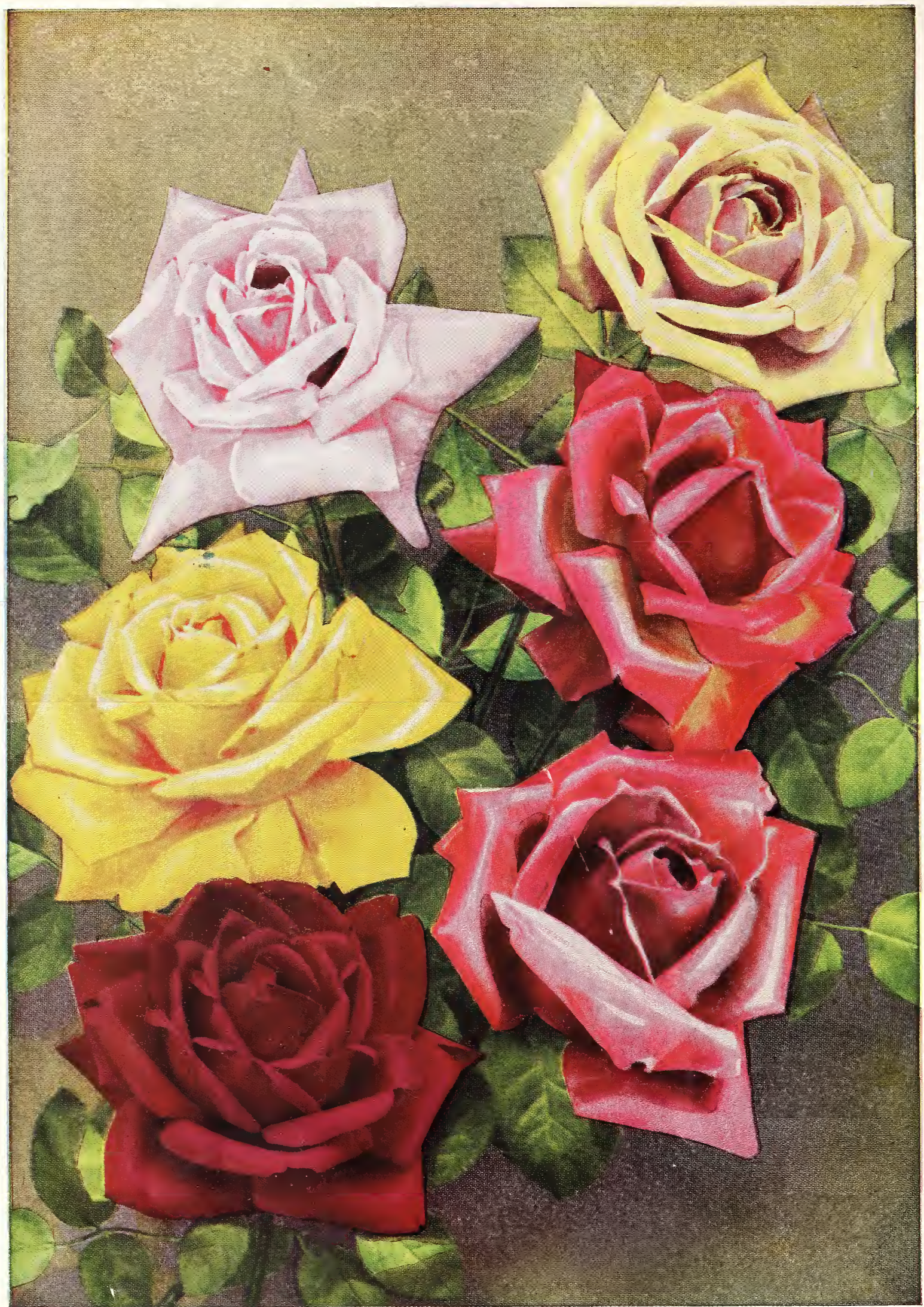

1. Madame Caroline Testout

2. Los Angeles

3. Hoosier Beauty 